\title{
Getting Past Possession: Subsurface Property Disputes as Nuisances
}

Joseph A. Schremmer

University of New Mexico - School of Law

Follow this and additional works at: https://digitalrepository.unm.edu/law_facultyscholarship

Part of the Law and Society Commons, Natural Resources Law Commons, Oil, Gas, and Mineral Law Commons, Physical and Environmental Geography Commons, Property Law and Real Estate Commons, and the Urban, Community and Regional Planning Commons

\section{Recommended Citation}

Joseph A. Schremmer, Getting Past Possession: Subsurface Property Disputes as Nuisances, 95 Washington Law Review 315 (2020).

Available at: https://digitalrepository.unm.edu/law_facultyscholarship/750

This Article is brought to you for free and open access by the School of Law at UNM Digital Repository. It has been accepted for inclusion in Faculty Scholarship by an authorized administrator of UNM Digital Repository. For more information, please contact amywinter@unm.edu, Isloane@salud.unm.edu,sarahrk@unm.edu.

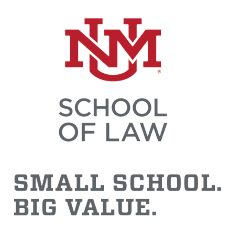

BIG VALUE. 


\title{
GETTING PAST POSSESSION: SUBSURFACE PROPERTY DISPUTES AS NUISANCES
}

\author{
Joseph A. Schremmer*
}

\begin{abstract}
Property rights in the subsurface of land are adapting to accommodate modern activities like massive hydraulic fracturing (fracking). Property rights will need to continue adapting if they are going to accommodate other developing activities like large-scale carbon capture and storage (CCS). Courts and commentators rarely approach the nature of subsurface property directly. They tend instead to discuss appropriate standards for tort liability when disputes arise - for example when artificial fissures from a frac treatment extend into and drain oil or gas from a neighbor's land. The case law and literature generally approach unauthorized subterranean invasions as trespasses. Because the tort of trespass is designed to protect possession, its application indicates a view of subsurface property as possessory (or corporeal) in nature.
\end{abstract}

Despite calling subsurface invasions "trespasses," courts rarely impose liability for, or enjoin, invasions themselves. They instead find liability only for interferences with existing or foreseeable uses of the affected land. Leading scholars likewise advocate for a standard of subsurface "trespass" that would privilege encroachments that are societally valuable, and award compensation only for resulting harm to existing uses of the property. The cases and literature thus nominally apply trespass but modify the tort from a property rule into a liability rule resembling the tort of nuisance.

This Article is the first to examine unauthorized subsurface encroachments as nuisances, rather than trespasses, and to assert that such encroachments do not implicate possession. Drawing on geology, doctrine, and property theory, this Article interrogates the assumption that subsurface property is possessory. It analyzes prominent subsurface "trespass" cases involving waste disposal, enhanced oil recovery, fracking, natural gas storage, slant-hole wells, tunneling, and horizontal drilling to demonstrate that these disputes are already being resolved under nuisance-like principles. It argues that express application of nuisance law is doctrinally correct and would improve courts' reasoning, harmonize disparate results, and more efficiently allocate costs of subsurface activities. The Article then discusses how viewing subsurface invasions as nuisances would remove legal barriers to implementation of new and emerging climate change mitigating technologies that utilize subsurface pore space, such as CCS.

INTRODUCTION 316

I. THE SUBSURFACE: RESERVOIR GEOLOGY AND COMMERCIAL USES ............................................... 320

A. Reservoir Geology in Brief........................................ 320

B. Commercial Uses of the Subsurface ........................... 321

C. Coordinating Conflicting Uses of a Common Reservoir 323

II. THE POSSESSION-BASED REGIME OF SUBSURFACE OWNERSHIP.

* Leon Karelitz Oil \& Gas Law Professor and Assistant Professor, University of New Mexico School of Law. I would like to thank Reed Benson for his insightful comments on an early draft. All errors are my own. 
A. The Common Law Background................................... 325

1. The Ad Coelum Doctrine ...................................... 325

2. Trespass as the Tort Remedy for Injury to Possession ....................................................... 326

B. Subsurface Ownership Literature .............................. 330

1. Focusing on Possession: The Subsurface Trespass Model ..................................................... 331

2. Focusing on Correlative Rights: Reservoir Community Analysis.............................................. 332

III. NUISANCE AS AN ALTERNATIVE TO

SUBSURFACE TRESPASS........................................... 333

A. Nuisance Law: A Jungle No More.............................. 334

B. The Restatement (Second)'s Approach to Nuisance. 336

C. The Nonpossessory Nature of

Subsurface Property Intrusions .................................. 338

1. What Is "Possession"? ............................................. 339

2. Is the Subsurface Property Interest Possessory?

IV. COURTS' NONTRESPASSORY TREATMENT

OF INVASIONS OF SUBSURFACE

PROPERTY INTERESTS ............................................... 342

A. Waste Disposal Cases ................................................. 343

B. Enhanced Recovery Cases ........................................... 352

C. Natural Gas Storage Cases......................................... 355

D. Tunneling and Directional Drilling Cases .................. 358

1. Tunnels Not for Oil and Gas Purposes.................. 358

2. Slant-Hole and Directional Wellbores .................. 360

E. Hydraulic Fracturing Cases........................................ 364

1. Fracking Resulting in Drainage .......................... 365

2. Frac Hits ........................................................... 370

F. Disputes Arising from CCS and Other Emerging Technologies ........................................... 373

\section{INTRODUCTION}

Oil, gas, and other hydrocarbons deposited within geologic reservoirs have long been scarce and valuable, and ownership rights in them are generally well defined. ${ }^{1}$ The subsurface rock structure and interstitial pore

1. Ownership of oil, gas, and other minerals is defined by the rule of capture. Subject to certain common law and statutory exceptions, under the rule of capture ownership of oil and gas vests in the owner of the producing well regardless of where the oil or gas migrated from. See JOHN S. LOWE ET AL., CASES \& MATERIAls ON Oil \& GAS LAW 56-116 (7th ed. 2018) (discussing ownership of minerals and the rule of capture); PATRICK H. MARTIN ET AL., CASES \& MATERIALS: THE LAW OF OIL \& GAS 17-75 (10th ed. 2016) (describing mineral ownership theories and the rule of capture); 
space in which hydrocarbons and connate fluids are deposited, on the other hand, have been less economically valuable. Property interests in the physical structure and pore space, accordingly, have not been clearly defined. ${ }^{2}$ Meanwhile, advancements in technology are enabling greater, more extensive uses of the subsurface structure and pore space itself. These include activities associated with energy and natural resources production, energy storage, and climate change mitigation through carbon capture and storage (CCS) and other emerging techniques. ${ }^{3}$ As geologic reservoir space becomes ever more useful, it is increasingly necessary to develop a clear regime of property rights to specify how subsurface owners may act within the reservoir and who may be benefitted and harmed by reservoir activities. ${ }^{4}$

Defining ownership of subsurface property is a precondition to defining tort duties relating to the property. ${ }^{5}$ Determining which tort applies when property is harmed depends on the specific property interest that is injured. Where the right of exclusive possession is injured, the applicable tort is trespass. ${ }^{6}$ By comparison, where the right of reasonable use and enjoyment is injured, the tort is nuisance. Analyzing how courts apply tort doctrine in subsurface property disputes reveals the nature of property interests in subsurface reservoir space. ${ }^{7}$

Proceeding from the implicit assumption that an interest in subsurface property is fully possessory, courts often call subsurface intrusions "trespasses." Yet courts rarely enjoin subsurface intrusions, and they generally determine liability for damages by balancing the social value of the actor's conduct against the gravity of harm to the complaining owner's

Jack C. Hazlewood, Oil and Gas-Protection of Adjoining Landowners-Drainage in Violation of Spacing Rules-Loeffler v. King, 29 TEX. L. REV. 111, 111 (1950) (discussing limitations placed on the rule of capture by conservation laws).

2. See generally Harold Demsetz, Toward a Theory of Property Rights, 57 AM. ECON. REV. (PAPERS \& PROC.) 347, 354-59 (1967) (hypothesizing the emergence of property rights in scarce resources as a function of their increasing value).

3. See infra section I.B.

4. See id. (discussing property rights primarily as a means of allocating the beneficial and harmful effects of development of the resource); see also Hannah J. Wiseman, Coordinating the Oil \& Gas Commons, 2014 BYU L. REV. 1543, 1575-76 (2014) (explaining how the definition of subsurface property rights affects private bargaining among rights holders for use of the subsurface property).

5. Mark D. Christiansen \& David E. Pierce, "When the Horizontal and Vertical Collide: Frac Hits and Operator Quest for Détente in the Common Reservoir," 61 ROCKY MTN. MIN. L. INST. 12-1, 1223 (2015).

6. See RESTATEMENT (FIRST) OF TORTS $§ 822$ (AM. LAW. INST. 1939) (defining "nuisance" as a nontrespassory invasion of a property interest).

7. See Guido Calabresi \& A. Douglas Melamed, Property Rules, Liability Rules, \& Inalienability: One View of the Cathedral, 85 HARV. L. REV. 1089, 1089 (1972) (presenting a framework of the various legal relationships treated by the separate subjects of property and torts). 
ability to use its property. ${ }^{8}$ Thus, while courts call subsurface invasions "trespasses," which would entail a property rule, they most frequently apply a liability rule resembling the tort of nuisance. ${ }^{9}$ Like the case law, much of the growing subsurface property literature nominally advocates for trespass as the tort to protect subsurface property. ${ }^{10}$ Also like the cases, however, the literature tends to modify trespass into a liability rule to reach desired results. ${ }^{11}$

Professor Owen Anderson's pathbreaking scholarship is the most notable example. Professor Anderson advocates for a modified trespass regime that would privilege nonconsensual subsurface intrusions whenever they accomplish an important societal need, and would award damages to the affected owner only for actual physical harm. ${ }^{12}$ While advocating for a liability rule, however, Professor Anderson expressly rejects a scheme based on nuisance law. ${ }^{13}$ His reasons include the area's historical reputation for being an "impenetrable jungle" and an apparent preference for strict liability for resulting damages. ${ }^{14}$ The rest of the literature has generally overlooked nuisance as an alternative.

This Article analyzes subsurface disputes as nuisances rather than trespasses. There are compelling reasons to prefer nuisance over trespass as the doctrinal response to subsurface intrusions. For one, as demonstrated in detail below, courts' treatment of subsurface invasions

8. See infra Part IV (reviewing subsurface invasion cases in the contexts of fluid injection, enhanced oil and gas recovery, natural gas storage, directional drilling and tunneling, and hydraulic fracturing).

9. See Calabresi \& Malemed, supra note 7, at 1092 (describing a property rule as one that protects the holder of an entitlement to injunction against one who wishes to transfer or destroy the entitlement and a liability rule as one that provides an entitlement holder damages for the forced transfer or destruction of the entitlement).

10. Scholars have written much about subsurface property rights, primarily in the context of oil and gas law. Broader scholarly interest in this area has been spurred recently by the prospect of using reservoir pore space for sequestering anthropogenic $\mathrm{CO}_{2}$ and other new technologies intended to mitigate climate change. See Tara K. Righetti, Correlative Rights \& Limited Common Property in the Pore Space: A Response to the Challenge of Subsurface Trespass in Carbon Capture \& Sequestration, 47 ENVTL. L. REP. NEWS \& ANALYSIS 10420, $10423 \mathrm{nn} .33-36$ (2017) (collecting scholarship on the legal viability of CCS projects with respect to potential trespass liability for transboundary migration of sequestered $\mathrm{CO}_{2}$ ).

11. See infra section II.B.

12. Owen L. Anderson, Subsurface "Trespass": A Man's Subsurface Is Not His Castle, 49 WASHBURN L.J. 247, 247-51 (2010) [hereinafter Anderson, Subsurface "Trespass]; Owen L. Anderson, Lord Coke, The Restatement, \& Modern Subsurface Trespass Law, 6 TEX. J. OIL GAS \& ENERGY L. 203, 204-07 (2010-2011) [hereinafter Anderson, Lord Coke].

13. Anderson, Lord Coke, supra note 12, at 205; Anderson, Subsurface “Trespass," supra note 12, at $247-48$.

14. Anderson, Lord Coke, supra note 12, at 205; Anderson, Subsurface "Trespass," supra note 12 , at 247-48 ("Critics may counter that certain types of deep subsurface invasions should not be within trespass law at all, but that such invasions should be left to the law of nuisance and negligence. I am reluctant to go this far."). 
resembles treatment of nuisances, which indicates that the property right implicated is use and enjoyment rather than possession. ${ }^{15}$ Additionally, nuisance protects landowners' interests with a liability rule, which is more flexible and context sensitive than a property rule, like trespass. Nuisance is thus better able to accommodate the factual complexities inherent in subsurface invasions and coordinate conflicting uses of reservoir space. ${ }^{16}$ Nuisance also furnishes a wider array of remedies, enabling more efficient allocation of the costs of reservoir activities among subsurface owners.

Even if analyzing subsurface property disputes as nuisances would not change the results in many or most cases, doing so would aid the coherence and predictability of courts' decision-making. This is not a trivial benefit. As the fledgling deployment of commercial-scale CCS illustrates,${ }^{17}$ uncertainty in subsurface property rights and liabilities stifles investment in, and development of, potentially beneficial technologies.

This Article proceeds as follows. Part I describes the physical interconnectedness of subsurface property and the resulting potential for subsurface use conflicts. Part II examines the doctrinal foundations of the prevailing exclusionary, or possession-based, view of subsurface property and reviews related literature. Sections III.A and III.B, respectively, introduce the history of nuisance law and the version of nuisance adopted in the Restatement (Second) of Torts. Section III.C theorizes that that an ownership interest in pore space is not fully possessory and thus not susceptible of trespass. Part IV attempts to confirm this theory by examining cases involving fluid injection, enhanced oil and gas recovery, natural gas storage, directional drilling and tunneling, and hydraulic fracturing. Part IV also demonstrates how these disputes would be resolved by expressly applying a nuisance framework. Part IV ends by discussing the application of nuisance principles to invasions caused by $\mathrm{CCS}$ and other emerging climate change mitigation techniques. Part V concludes that courts are already engaging in nuisance-like analyses, and that doing so expressly would aid the coherence of their decisions and

\section{See infra Part IV.}

16. For a discussion of exclusionary schemes, like trespass, versus governance schemes, like nuisance, see generally Henry E. Smith, Exclusion Versus Governance: Two Strategies for Delineating Property Rights, 31 J. LEGAL STUD. S453 (2002) (discussing use in the law of exclusion strategies, which place all decisions about use of a resource in a single owner, and governance strategies, which impose on a group of duty holders the task of defining and monitoring proper use of a common resource); see also Henry E. Smith, Exclusion \& Property Rules in the Law of Nuisance, 90 VA. L. REV. 965, 1024-45 (2004) (discussing nuisance's role in limiting a regime of exclusion thusly: "Nuisance rests on a foundation of exclusion, whether this is labeled trespass or nuisance, but it also fine-tunes this hard-edged regime where the stakes are high enough and courts have some advantage in providing off-the-rack governance rules").

17. See infra section I.C (discussing the slow roll out of CCS technology due in part to uncertainty in the legal rules governing liability for $\mathrm{CO}_{2}$ migration). 
reduce one barrier to investment in subsurface technologies: legal uncertainty.I.The Subsurface: Reservoir Geology and Commercial Uses

\section{A. Reservoir Geology in Brief}

The subsurface of the earth is complex. It is presently understood to consist of basically four internal layers - the crust, mantle, outer core, and inner core. ${ }^{18}$ Humans have never penetrated below the crust, ${ }^{19}$ and it is within this layer that we have explored and developed commercial uses of the subsurface. The crust consists of layered beds of rock formations with differing properties. Like a sponge, the interior of these rock structures consists of small, interconnected pathways known as pore spaces. ${ }^{20}$ These pore spaces are voids in the rock that can contain any number of fluid substances including air, freshwater, saltwater, and hydrocarbons like oil and gas. ${ }^{21}$ Together the physical structure of the rock and these pore spaces make up the crust of the earth.

A geologic "reservoir" is an interconnected subsurface rock structure that is under pressure from the overlying rock. ${ }^{22}$ As the pressure within one portion of a reservoir changes-for example from a penetrating wellbore - the pressure will change throughout the reservoir. Changes in pressure cause the fluids contained within reservoir pore spaces to move through the interconnected pathways toward areas of lower pressure. ${ }^{23}$ Fluids flow most freely within rock formations that have high porosity, meaning the rock has a high ratio of pore space versus solid space, and high permeability, which signifies a high degree of pore space interconnectivity. ${ }^{24}$ Together the properties of porosity and permeability determine a formation's suitability as a reservoir for oil or gas, waste disposal, or, as discussed below, CCS. ${ }^{25}$

18. John G. Sprankling, Owning the Center of the Earth, 55 UCLA L. REV. 979, 993 (2008).

19. Id. at 994 .

20. LOWE ET AL., supra note 1 , at 7.

21. Righetti, supra note 10 , at 10423 .

22. See LOWE ET AL., supra note 1, at 8, 21 (defining a "reservoir" and describing the types of reservoir drives).

23. See Sidney J. Strong, Application of the Doctrine of Correlative Rights by the State Conservation Agency in the Absence of Express Statutory Authorization, 28 MONT. L. REV. 205, passim (1967) ("Unlike solid minerals, oil and gas are fugacious or they tend to migrate from areas of high pressure to areas of low pressure." (citing 1 SUMMERS, OIL AND GAS $\S 4$ (2d ed. 1954); SulLivan, OIL AND GAS LAW $\S 7$ (1955))).

24. Itzchak E. Kornfeld, Geology, The Marcellus Shale, Experts, \& Dispute Resolution, 116 W. VA. L. REV. $865,876,884$ (2014).

25. Id. at 876 . 


\section{B. Commercial Uses of the Subsurface}

Geologic reservoirs have many established and potential commercial uses, most of which involve exploitation of hydrocarbons contained within the pore space of the physical strata. ${ }^{26}$ These activities include the injection of fluids into subsurface strata for oil and gas production. Some of the most common fluid injection activities are hydraulic fracturing, ${ }^{27}$ secondary and enhanced recovery, ${ }^{28}$ and disposal of produced saltwater as a byproduct of production. ${ }^{29}$ When natural gas is produced it is frequently stored for later sale or use through injection into subsurface reservoirs. Further, under the federal Underground Injection Control (UIC) program, hazardous and nonhazardous fluid wastes are injected into relatively deep reservoirs for disposal. ${ }^{30}$

In addition to these longstanding subsurface activities, new uses for the subsurface are emerging. Emerging uses include compressed air energy storage (CAES) and underground aquifer storage and recovery (ASR) of groundwater. ${ }^{31}$ CAES is designed to store surplus electricity produced by wind power generation to manage the complications imposed by the inherent intermittence of wind. CAES diverts electricity that would have otherwise been delivered into the electric grid and uses it to compress and pump air into deep reservoirs for storage. The air can then be drawn upon as needed to operate natural gas turbines more efficiently. ${ }^{32}$ ASR refers to the injection of freshwater into deep reservoirs for later retrieval. ${ }^{33}$ Other

26. Modern drilling for oil and gas started in earnest in the latter half of the nineteenth century. DANIEl Yergin, THE PRIZE: The EPIC Quest FOR OIL, MONEY \& POWER 12-15 (Free Press 2009). With oil and gas drilling came a variety of related underground operations designed to stimulate production. One early and dramatic example was detonating nitroglycerin in the bottom of a well. See, e.g., People's Gas Co. v. Tyner, 31 N.E. 59, 59 (Ind. 1892). After World War II oil and gas developers began stimulating wells by hydraulically fracturing the productive geologic formations through injection of pressurized water, sand, and chemicals in a process known as "hydraulic fracturing" or "fracking." NORMAN J. HYNE, NONTECHNICAL GUIDE TO PETROLEUM GEOLOGY, EXPloration, DRILling, \& PRODUCTION 423-24 (2d ed. 2001). Together with horizontal drilling, hydraulic fracturing became a standard means of extracting oil and gas from unconventional, or "tight," shale formations previously uneconomic to produce. Id.

27. See infra section IV.E.

28. See infra section IV.B.

29. See infra section IV.A.

30. See infra section IV.A.

31. R. Lee Gresham \& Owen L. Anderson, Legal and Commercial Models for Pore-Space Access and Use for Geologic CO2 Sequestration, 72 U. PITT. L. REV. 701, 706-07 (2011).

32. Id. (citing Paul Denholm \& Ramteen Sioshansi, The Value of Compressed Air Energy Storage with Wind in Transmission-Constrained Electric Power Systems, 37 ENERGY POL'Y 3149-50 (2009)).

33. Id. at 707 (citing Peter J. Kiel \& Gregory A. Thomas, Banking Groundwater in California: Who Owns the Aquifer Storage Space?, 16 NAT. RESOURCES \& ENV'T 25, 25 (2003)). ASR is currently practiced in certain dry western states including Texas and Colorado. COLO. REV. STAT. ANN. § 379-107.5 (West 2020) (authorizing aquifer storage-and-recovery plans in Colorado); TEX. WATER CODE ANN. $\S$ 27.151-.157 (West 2020) (authorizing ASR projects). 
uses of the storage capacity of geologic reservoirs are certain to develop in the future.

Currently, the most notable emerging pore space technology-CCSis potentially the most significant and likeliest to lead to complications with other subsurface activities. CCS emerged as a tool to mitigate climate change. ${ }^{34}$ It has the potential to reduce the rate of climate change by capturing and storing, or "sequestering," anthropogenic carbon dioxide $\left(\mathrm{CO}_{2}\right)$ emissions into deep subsurface reservoirs for storage on a geologic time scale. ${ }^{35}$ In CCS, "the gas is compressed to a supercritical fluid and injected a kilometer or deeper in to the microscopic 'pore space' in the deep subsurface rock matrix, displacing the in situ brine," for instance, the saltwater naturally in place in the pore space. ${ }^{36}$

CCS evolved from technologies developed for oil and gas recovery and storage. ${ }^{37}$ Depleted oil and gas reservoirs are excellent $\mathrm{CO}_{2}$ storage sites because they provide adequate pore space capacity and porosity and permeability, have already been explored and characterized, and can mostly contain the migration of injected $\mathrm{CO}_{2}{ }^{38}$ Other types of geologic formations that are useful for $\mathrm{CO}_{2}$ storage include deep saline reservoirs and un-mineable coal seams. ${ }^{39}$ The United States Department of Energy estimates that the United States has the capacity to store at least 2,400 billion metric tons of man-made $\mathrm{CO}_{2}{ }^{40}$ This capacity could offset centuries' worth of the country's total $\mathrm{CO}_{2}$ emissions from large stationary sources. ${ }^{41}$

34. A consensus of scientists has concluded that control of greenhouse gas emissions is necessary to avoid "severe and irreversible changes to natural ecosystems" and significant negative impacts on public health, agriculture, food supply, forests, water resources, and even energy production itself. Alexandra B. Klass \& Elizabeth J. Wilson, Climate Change, Carbon Sequestration, and Property Rights, 2010 U. ILL. L. REV. 363, 368 (2010) (quotations omitted).

35. Michael G. FAure \& Roy A. PARTAin, CARBon CAPTURE AND STORAGE: EFficient LEGAL POLICIES FOR RISK GOVERNANCE AND COMPENSATION 2 (2017). This Article will refer to the process as "CCS" for convenience.

36. Klass \& Wilson, supra note 34, at 365; see also Righetti, supra note 10, at 10423 (describing pore space as a "split bone").

37. FAURE \& PARTAIN, supra note 35 , at 11.

38. Id. at 16 .

39. Peter Folger, CONG. ReSEARCh SERVS., CARBOn Dioxide CAPTURE AND SEQUESTRATION(CCS) IN THE UNITED STATES 7 (2018), https://fas.org/sgp/crs/misc/R44902.pdf [https://perma.cc/F9CM-FFAC].

40. U.S. Dep't of Energy, DOE's Carbon Utilization and Storage Atlas Estimates at Least 2,400 Billion Metric Tons of U.S. CO2 Storage Resource, OFF. FossiL ENERGY (Dec. 19, 2012), https://www.energy.gov/fe/articles/does-carbon-utilization-and-storage-atlas-estimates-least-2400 [https://perma.cc/2QT6-5CMD].

41. FOLGER, supra note 39 , at 8 . 


\section{Coordinating Conflicting Uses of a Common Reservoir}

Because reservoirs are interconnected, any activity in one portion of a reservoir will to some extent affect the pressure in other parts. By virtue of porosity and permeability, fluid that is injected into a reservoir tends to migrate away from the injection location toward areas of lower pressure and occupy pore spaces in distant parts of the reservoir. ${ }^{42}$ Subsurface activities, like hydraulic fracturing and fluid injection and storage, thus directly and indirectly affect large areas of subsurface property and often interfere with subsurface activities in other parts of the same reservoir. This interconnectedness, Professor David Pierce notes, means that "[e]ach oil and gas reservoir comprises a community of owners. ${ }^{, 43}$ Disputes arise between members of a reservoir community when one member's activities cause changes in pressure and fluid migration in a portion of the reservoir underlying another member's land. Such subsurface disputes are more complex than disputes over the ownership and use of the surface of property because the subsurface is geologically complex and hidden from view. ${ }^{44}$

The history of CCS illustrates the practical problems that arise from interconnectedness of subsurface property. There has not been large-scale deployment of existing CCS technology despite abundant potential storage sites and favorable legislation. ${ }^{45}$ Commercial CCS projects are rare - but not necessarily because they are commercially infeasible. A recently renewed federal tax credit may even make projects economically attractive. ${ }^{46}$ A primary obstacle to large-scale deployment of CCS instead appears to be the extent of subsurface area required for a single storage facility. This problem arises from the inevitable transboundary migration of injected $\mathrm{CO}_{2} \cdot{ }^{47}$ Various studies indicate that injected $\mathrm{CO}_{2}$ sequestered

42. LOWE ET AL., supra note 1, at 16-18.

43. David E. Pierce, Resolving Intra-Reservoir Horizontal Drilling Conflicts Using a Reservoir Community Analysis, 90 N.D. L. REV. 249, 250 (2014) (citing JOHN S. LOWE ET AL., CASES \& MATERIALS ON OIL \& GAS LAW 21 (6th ed. 2013)).

44. See Christopher S. Kulander \& R. Jordan Shaw, Comparing Subsurface Trespass JurisprudenceGeophysical Surveying and Hydraulic Fracturing, 46 N.M. L. REV. 67, 67-68 (2016).

45. See FolgER, supra note 39, at 1 (noting a number of bills introduced in the 115 th Congress intended to incentivize implementation of CCS); Klass \& Wilson, supra note 34, at 364.

46. See 26 U.S.C. § 45Q (Supp. 2012) (“Credit for carbon dioxide sequestration.”).

47. See LOWE ET AL., supra note 1, at 91 n.7 ("Requiring project developers to obtain consent from all pore-space owners within the migratory path of the $\mathrm{CO}_{2}$ plume could have the practical effect of prohibiting many sequestration projects."); Righetti, supra note 10, at 10423 ("Scholars have recognized the issue of transboundary migration and trespass as critical to the practical, legal, and economic viability of CCS projects." (citing James Robert Zadick, The Public Pore Space: Enabling Carbon Dioxide Capture and Sequestration by Reconceptualizing Subsurface Property Rights, 36 WM. \& MARY ENVTL. \& POL'Y REV. 257, 269 (2011))). 
in the subsurface could migrate laterally hundreds or thousands of square miles. ${ }^{48}$

The propensity of injected $\mathrm{CO}_{2}$ to migrate over such large areas creates two legal risks that stifle investment in sequestration projects. The first is the risk of trespass. Under the doctrine of ad coelum, an owner of real property is deemed to own the earth below the property's surface boundaries. ${ }^{49}$ In much of the United States, land ownership is highly subdivided into relatively small, separately owned tracts. Consequently, many owners may have rights in a single reservoir and, migrating $\mathrm{CO}_{2}$ may trespass on the rights of owners far beyond the area acquired for injection. The theoretical solution, which is not always practically possible, is to obtain such owners' consent to use their pore space for sequestration. ${ }^{50}$ Second, migrating $\mathrm{CO}_{2}$ may interfere with other commercial subsurface activities such as primary and enhanced oil recovery, waste disposal, and natural gas storage. Migration is thus likely to foment disputes between the $\mathrm{CO}_{2}$ injector and the competing user unless the competing user has consented. ${ }^{51}$ The problem is compounded because $\mathrm{CO}_{2}$ sequestration projects are likely to be sited in depleted oil and gas reservoirs where preexisting operations for oil and gas recovery and waste disposal may be ongoing.

While these issues may impact CCS projects especially because of the size of the subsurface area where sequestered $\mathrm{CO}_{2}$ is likely to migrate, they arise on some scale any time the subsurface is used for extracting or injecting fluids. The legal uncertainty helping to stifle large-scale deployment of CCS illustrates the need for a system of defining and ordering the competing interests of subsurface rights holders over vast areas. As discussed in the following section, courts and scholars often employ a possession-based analysis to resolve competition among conflicting subsurface activities.

48. LOWE ET AL., supra note 1, at 91 n.7 (collecting scholarly studies). One study predicted injected $\mathrm{CO}_{2}$ could disperse over 100 square kilometers within the first 30 years of sequestration. Sprankling, supra note 18 , at 1030 .

49. See infra section II.A.1 (discussing the ad coelum doctrine).

50. A few states have enacted unitization statutes for consolidating pore space for CCS. E.g., WYO. STAT. ANN. $\S \S 35-11-313$ to -316 (West 2020).

51. Gresham \& Anderson, supra note 31 , at 771. 


\section{THE POSSESSION-BASED REGIME OF SUBSURFACE OWNERSHIP}

\section{A. The Common Law Background}

\section{The Ad Coelum Doctrine}

Discussion of the nature and extent of subsurface ownership starts with the ad coelum doctrine. The doctrine derives from the Latin maxim cujus est solum, ejus est usque ad coelum et ad infernos, which holds that the rights of the surface owner extend infinitely upward "to the heavens" and downward "to hell" or the center of the earth. ${ }^{52}$ Ad coelum extends surface boundaries downward, theoretically, to the earth's core. Noting that the earth is round, a Louisiana court has pointed out that under ad coelum, "a surface tract's subsurface measurement must necessarily narrow as it approaches the center point of the earth. Ownership of subsurface tracts equal in size to surface tracts would result in overlapping boundaries as the available area diminishes. ${ }^{\circ 3}$ Thus surface property boundaries are not directly indicative of subsurface boundaries.

Under ad coelum, ownership of the surface of land includes ownership of the underlying minerals. ${ }^{54}$ The owner can sever ownership of oil, gas, and other minerals to create two estates, the mineral estate and the surface estate, each capable of separate ownership in fee. ${ }^{55}$ Land titles often become complex where the surface and mineral estates are partially or completely severed in this manner. Determining title to the mineral estate and surface state requires determining title to each component part of the subsurface. ${ }^{56}$ It is generally accepted that the subsurface consists of three basic component parts: (1) the physical strata, or the "subsurface mass,"

52. Kulander \& Shaw, supra note 44, at 71; Sprankling, supra note 18 , at $982-84$. For a thorough and persuasive critique of the ad coelum doctrine, see generally Sprankling, supra note 18.

53. Nunez v. Wainoco Oil \& Gas Co., 488 So. 2d 955, 959 n.9 (La. 1986).

54. 1 Eugene Kuntz, A Treatise On the LAw OF Oil \& GAS § 60-1 (1987) (“Ownership of land carries with it ownership of or the exclusive right to enjoy substances under the surface...."); see, e.g., De Moss v. Sample, 78 So. 482, 485 (La. 1918) ("It need not be restated that the ownership of the surface of the earth carries with it the right to the minerals beneath . ...").

55. See e.g., De Moss, 78 So. at 482. ("The elements of ownership in land may be severed. The owner may sell surface rights, and except from the sale the minerals below the surface, and reserve to himself the right to mine those minerals ...."). Courts and scholars quickly understood that $a d$ coelum was, "inadequate to solve the problems of a substance under the earth, which would migrate to points of lower pressure caused by punctures of the reservoir by drilling," and eventually adopted the rule of capture, the doctrine of correlative rights, and conservation regulation to govern ownership of oil and gas in common reservoirs. See Nunez v. Wainoco Oil \& Gas Co., 488 So. 2d 955, 962 (La. 1986) (quoting H. DAGgetT, Mineral Rights IN LOUISIANA 415 (1949)). These principles do not necessarily apply equally to the rock strata and pore space within which hydrocarbons are found.

56. Kulander \& Shaw, supra note 44, at 68.

57. Dunn-McCampbell Royalty Interest, Inc. v. Nat'1 Park Serv., 630 F.3d 431, 442 (5th Cir. 2011). 
that comprises the earth's structure; (2) the void pore spaces within the physical strata; and (3) the fluid substances within the pore spaces. ${ }^{58}$

There is little doubt in any jurisdiction that the owner of the surface estate owns title to the subsurface mass, and that the mineral estate owner owns the hydrocarbon substances within the pore spaces. In many states, however, it is not clear which of the two owns the pore space itself. Some states have declared by statute that pore space ownership belongs to one estate or the other, but even clear legislative intent does not necessarily clarify title. ${ }^{59}$ The majority rule - among both states with a statutory declaration and common law states - appears to be that the pore space is included in the surface estate unless specifically conveyed (or reserved) in a severance of the mineral estate. ${ }^{60}$ Thus in a majority of jurisdictions the surface estate owner is deemed to own fee simple in the physical strata and pore space underlying the surface boundaries of her tract to the center of the earth.

\section{Trespass as the Tort Remedy for Injury to Possession}

At common law the fee owner holds the absolute exclusive right to possess the land subject to the fee. The United States Supreme Court has even said the right to exclude others is "one of the most essential sticks in the bundle of rights that are commonly characterized as property." 61 Contemporary scholars have gone further and described the right to exclude as the essential element of property. ${ }^{62}$ The common law remedy for enforcing an owner's exclusive possessory interest in land is the tort of trespass.

58. See Righetti, supra note 10, at 10423-34 (noting the subsurface is like a "split bone-despite the calcified and compact exterior, the inside is spongy, or cancellous; between the mesh-like sheets and spikes of bone are tiny cavities filled with marrow").

59. See id. at 10424 (discussing several nuances affecting title to pore space even in states with a clear legislative declaration).

60. Id. at 10425 (citing Stefanie L. Burt, Who Owns the Right to Store Gas: A Survey of Pore Space Ownership in U.S. Jurisdictions, 4 JOULE DuQ. ENERGY \& ENVTL. L.J. (2016), http://www. duqlawblogs.org/joule/wp-content/ uploads/2016/07/Who-Owns-the-Right-to-Store-Gas-A-Surveyof-Pore-Space-Ownership-in-U.S.-Jurisdictions-.pdf (last visited Jan. 30, 2020)). Certain states, like Kansas, have not directly addressed the pore space ownership question but have held that the surface estate is entitled to authorize fluid injection, which strongly implies ownership of the pore space. See Dick Props., LLC v. Paul H. Bowman Tr., 221 P.3d 618, 618 - 1-6 (Kan. Ct. App. 2010).

61. Dolan v. City of Tigard, 512 U.S. 374, 384 (1994) (internal quotation marks omitted) (quoting Kaiser Aetna v. United States, 444 U.S. 164, 176 (1979)).

62. Thomas W. Merrill, Property and The Right to Exclude, 77 NEB. L. REV. 730, 730 (1998); see also Carol M. Rose, Possession as the Origin of Property, 52 U. CHI. L. REV. 73, 75 (1985) (stating that at common law first possession was the root of title). 
Modern treatises define trespass as the "wrongful interference with the right of exclusive possession of real property." ${ }^{63}$ At early common law trespass included several different actions, each directed at a different kind of wrong. Trespass quare clausum fregit ("breaking a close") was limited to direct physical invasions of exclusive possession. As one early twentieth century court explained, "[i]t is, of course, axiomatic that at common law the gist of the action of trespass quare clausum fregit is injury to the possession, and that, generally speaking, the plaintiff must show actual or constructive possession at the time of the trespass." ${ }^{.64}$ Contrastingly "indirect and consequential" injuries arising from nonphysical invasions were remedied under the writ of trespass on the case. ${ }^{65}$ Trespass on the case was also brought to enforce nonpossessory, or incorporeal, property rights like easements and licenses. ${ }^{66}$ Unlike trespass quare clausum fregit, trespass on the case required proof of actual injury and did not entitle the plaintiff to ejectment or nominal damages. ${ }^{67}$ Claims of nuisance were, under the writ system, brought as claims for trespass on the case. ${ }^{68}$

The traditional common law remedies for trespass quare clausum fregit were designed to enforce the owner's exclusivity of possession. That design is reflected in the modern remedies for trespass: injunctive relief, ejectment, restitution, and nominal and compensatory damages. ${ }^{69}$ Recovery for trespass quare clausum fregit is allowed without proof of damages. Rather "the law infers some damage without proof of actual

63. 66 C.J.S. Nuisances $\S 2$ (2019) ("The tort of trespass applies to the wrongful interference with the right of exclusive possession of real property ....").

64. Slye v. Guerdrum, 29 App. D.C. 550, 552 (D.C. 1907).

65. See Sutherland v. Saint Francis Hosp., Inc., 595 P.2d 780, 783 (Okla. 1979) (discussing the "ancient subtleties" that characterized the writ system).

66. Osborne M. Reynolds, Jr., Distinguishing Trespass and Nuisance: A Journey Through a Shifting Borderland, 44 OKLA. L. REV. 227, 253 (1991).

67. Coastal Oil \& Gas Corp. v. Garza Energy Tr., 268 S.W.3d 1, 9-10 (Tex. 2008) (citing W. PAGE KeEton et AL., Prosser \& KeEton On THE LAW OF TORTS $§ 13$, at 78 (5th ed. 1984)).

68. Stuart S. Ball, The Vertical Extent of Ownership in Land, 76 U. PENN. L. REV. 631, 652 (1928). American courts largely abandoned the common law forms of action and the writ system in the latter half of the nineteenth century. Stephen C. Dillard et al., Nuisance Cases Against Energy Companies in Texas, Pennsylvania, and Other Areas with Significant or Developing Oil and Gas Exploration, 59 S. TEX. L. REV. 447, 450-53 (2018). Yet some jurisdictions still recognize trespass on the case as a cause of action for interference with a nonpossessory interest in land. As the Texas Supreme Court (which still recognizes an action for trespass on the case by owners of nonpossessory interests) reminded the plaintiffs in Coastal Oil \& Gas Corp. v. Garza Energy Tr., "[a]t common law, trespass included several actions directed to different kinds of wrongs. Trespass quare clausum fregit was limited to physical invasions of plaintiff's possessory interest in land; trespass on the case was not." 268 S.W.3d at 9 (internal citations omitted).

69. Righetti, supra note 10, at 10429 (collecting authorities for each remedy). 
injury" from direct invasions of property. ${ }^{70}$ The inference of damages is justified by a variety of policy reasons including "to prevent the acquisition of a prescriptive right, to settle a dispute regarding title, to vindicate a property right, and because trespass was so likely in early times to lead to a breach of the peace." 71 The presumption of damages is necessary to protect the owner's exclusivity of possession, which is injured by the mere fact of an unauthorized invasion. Requiring an owner to show actual damages to recover for a trespass, on the other hand, " "would place a premium on trespassing' by 'mak[ing] the position of the trespasser more favorable" " than that of the owner. ${ }^{72}$

Common law trespass is subject to few defenses. The primary defense for nonnegligent trespasses - necessity-is narrow. Necessity allows unauthorized entry when it is reasonably necessary to preserve property or life, prevent serious bodily harm to a third person, or escape bodily injury. ${ }^{73}$ Even where the defense applies, the resulting privilege is incomplete because the actor remains liable for compensating the property owner for actual damages caused by the privileged trespass. ${ }^{74}$

Courts' application of trespass quare clausum fregit has evolved to conform to modern realities. For example some states still follow the traditional rule (or, sometimes, the "dimensional test") requiring a direct invasion by an object that is visible to the human eye to constitute a trespass. ${ }^{75}$ Many other states, recognizing the lesson of particle physics that energy and matter are equal, have rejected the dimensionality test in favor of focusing on the type of interest invaded. The leading case rejecting the dimensionality test is Martin v. Reynolds Metals $C o{ }^{76}$ There,

70. 17A Carmody-Wait NeW York Practice, Nominal Damages in Actions for Trespass to Land § 107:137 (2d. ed. 2019) (emphasis added).

71. Page Keeton \& Lee Jones, Jr., Tort Liability and the Oil and Gas Industry II, 39 TEX. L. REV. 253, 256-57 (1961).

72. Sakele Bros., LLC v. Safdie, 302 A.D.2d 20, 27 (N.Y. App. Div. 2002) (quoting De Camp v. Bullard, 54 N.E. 26, 28 (N.Y. 1899)). For example, under the traditional view of trespass the owner of Blackacre would be entitled to sue his neighbor for nominal damages and ejectment in response to her neighbor's crossing Blackacre as a shortcut to a public street even if Blackacre suffered no harm. In fact, the owner of Blackacre would have a legal obligation to sue to prevent the neighbor from gaining a prescriptive right in Blackacre. See Kyle Graham, The Continuing Violations Doctrine, 43 GONZ. L. REV. 271, 309-10 (2008). Without an inference of damages enabling Blackacre's owner to sue for ejectment, the neighbor's trespass would effectively be privileged over the owner's right of exclusive possession, and Blackacre's owner would have no legal remedy to prevent loss of title by prescription or adverse possession. See generally Francis H. Bohlen, Incomplete Privilege to Inflict Intentional Invasions of Interests of Property and Personality, 39 HARV. L. REV. 307 (1926) (describing the defense of necessity to trespass as an "incomplete privilege").

73. 87 C.J.S. Trespass $§ 36$ (2019).

74. Bohlen, supra note 72 , at 312-13.

75. Bortland v. Sanders Lead Co., 369 So. 2d 523, 527 (Ala. 1979) (citing 1 HARPER \& JAMES, TORTS $§ 1.23$ (1946)).

76. 342 P.2d 790 (Or. 1959) (en banc). 
the Oregon Supreme Court held that intrusion by invisible fluoride particles constituted a trespass. ${ }^{77}$ The court theorized that the "direct" and "physical" elements of a traditional common law tort action were merely judges' attempt to describe the types of invasions that interfere with possession. ${ }^{78}$ In discerning the appropriate cause of action as between trespass and nuisance in a borderline case, the Martin Court focuses on the nature of the interest impacted by the defendant's conduct instead of the physical nature of the intrusion. ${ }^{79}$

Trespass and ad coelum also morphed to meet modern needs in the form of commercial air travel. In 1946 the United States Supreme Court in United States v. Causby ${ }^{80}$ noted that ad coelum has no place in the modern world and held that a landowner has no common law right to stop airplane flights high over her property. ${ }^{81}$ Under Causby and its progeny, landowners are entitled to damages for actual injury caused by use of the airspace above their land but not to any remedy for the unauthorized entry of the property itself. ${ }^{82}$ The Restatement (Second) of Torts incorporated Causby's conception of airspace trespass. ${ }^{83}$ Courts continued to label air invasions as "trespasses" for decades until eventually coming to view "that any liability should be in nuisance and should thus depend on whether there was unreasonable and substantial interference with the surface." ${ }^{\prime 4}$

While courts were expressly limiting the ad coelum doctrine in the context of overlying airspace they were also implicitly limiting its application to the underlying subsurface.$^{85}$ As examined closer below, ${ }^{86}$ the advent of modern hydrocarbon production techniques triggered a spate of litigation over subsurface interferences. These disputes have resulted in a multitude of doctrinally confused, logically inconsistent, resultoriented decisions.$^{87} \mathrm{~A}$ sizeable literature considering the rights and

77. Id. at 797.

78. Id. at 793 .

79. Id. at 794 ("Viewed in this way we may define trespass as any intrusion which invades the possessor's protected interest in exclusive possession, whether that intrusion is by visible or invisible pieces of matter or by energy which can be measured only by the mathematical language of a physicist.").

80. 328 U.S. 256 (1946).

81. Id. at 261.

82. See Reynolds, supra note 66 , at 235-36.

83. Restatement (SECOND) OF TORTS $§ 159$ (AM. LAW InST. 1969).

84. Reynolds, supra note 66, at 236-37.

85. See Kulander \& Shaw, supra note 44, at 73; see also infra Part IV.

86. See infra Part IV.

87. See, e.g., Gresham \& Anderson, supra note 31, at 723 ("However, the case law is neither entirely unified nor coherent."); Sprankling, supra note 18, at 1020 (noting the inconsistency in case law dealing with landowners' rights more than two miles below the surface). 
remedies of owners of subsurface property interests developed in response.

\section{B. Subsurface Ownership Literature}

Commentators have advanced multiple models of subsurface property. Several commentators urge eliminating any private property rights in the deep subsurface and making it a public domain. ${ }^{88}$ Others would empower private actors to employ eminent domain authority to consolidate pore space within a common reservoir for specific purposes such as CCS projects. ${ }^{89}$ While approaches like these may be effective in encouraging deployment of particular technologies like CCS, they take a piecemeal approach to governing use of the subsurface. They would also require significant legislation and the creation of new bureaucracies for implementation.

Even where a regulatory regime authorizes the creation of compulsory units of property for particular subsurface activities, those units must necessarily share boundaries with non-unitized property. And because administrative agencies typically lack the authority to adjudicate common law causes of action or license private actors to commit torts, ${ }^{90}$ the creation of a unit for any particular purpose may not preclude an action by an owner outside of the unit for common law trespass. ${ }^{91}$ Therefore, even where subsurface rights are consolidated administratively, it is necessary to determine the extent of the ownership rights of nonconsenting owners.

Other scholars have advanced alternative models of subsurface property that could address all kinds of subsurface uses and interferences. Two predominant models have emerged - one that views subsurface rights within a trespass-based framework and one that focuses instead on

88. Righetti, supra note 10, at 10434 (citing Spranking, supra note 18, at 1032; A. Bryan Endres, Geologic Carbon Sequestration: Balancing Efficiency Concerns and Public Interest in Property Rights Allocations, 2011 U. ILL. L. REV. 623, 646-49 (2011); Kevin L. Doran \& Angela M. Cifor, Does the Federal Government Own the Pore Space Under Private Lands in the West?, 42 ENVTL. L. 527, 545 (2012); Zadick, supra note 47; Will Reisinger et al., Reconciling King Coal and Climate Change: A Regulatory Framework for Carbon Capture and Storage, 11 VT. J. ENVTL. L. 1, 33 (2009)). Professor Wiseman would not abolish private rights but has suggested the need for public intervention in coordination of subsurface rights in the form of "subsurface comprehensive planning and zoning." Wiseman, supra note 4, at 1576.

89. See, e.g., Klass \& Wilson, supra note 34, at 425.

90. See Gresham \& Anderson, supra note 31, at 734-35 (noting that "[a]s with title issues, regulatory bodies have no general authority to authorize trespasses or other torts," and citing cases).

91. Righetti, supra note 10, at 10437 (citing Bruce M. Kramer, Horizontal Drilling and Trespass: A Challenge to the Norms of Property and Tort Law, 25 COLO. NAT. RESOURCES ENERGY \& ENVTL. L. REV. 291 (2014)). 
the correlative nature of subsurface property. The following subsections will briefly review the two dominant models.

\section{Focusing on Possession: The Subsurface Trespass Model}

A majority of the literature advocates for application of a modified approach to subsurface trespass similar to the modern trespass rule established in Causby. ${ }^{92}$ The leading voice in this area is Professor Owen Anderson. ${ }^{93}$ Anderson concludes that "[w]henever the trespasser's subsurface intrusion accomplishes an important societal need, including private commercial needs, and so long as the subsurface owner suffers no actual and substantial damages, subsurface trespass should not be actionable." 94 Under this regime courts may not enjoin subsurface intrusions deemed socially desirable that do not cause actual harm. ${ }^{95}$ However, where an intrusion causes damage beyond the fact of the intrusion to the complaining owner, the trespasser would be strictly liable for compensation. ${ }^{96}$ Anderson states that his approach redefines a fee interest in subsurface property so as not to encompass the right to exclude socially desirable intrusions. Per Anderson, "property ... denote[s] legal relations between persons with respect to a thing," and so, "[w]hile the right to exclude trespassers is a fundamental incident of property ownership, the right, like other incidents, neither is nor should be absolute." ${ }^{.97}$ Stated another way, Anderson's approach modifies trespass from a property rule into a liability rule under which the owner is not entitled to injunction to protect its entitlement but instead may only obtain compensatory damages for infringement of its entitlement. ${ }^{98}$

Aspects of Professor Anderson's subsurface "trespass" rule closely resemble principles of nuisance law, particularly as reflected in the Restatement (Second) of Torts. Professor Anderson's standard, for example, would consider the "societal need" for the interfering activity and the degree of harm to the complaining party in a sort of "balance of utilities" test. ${ }^{99}$ Yet Anderson expressly rejects nuisance as an analytical

92. See generally, e.g., Anderson, Subsurface "Trespass," supra note 12; Anderson, Lord Coke, supra note 12; Keith B. Hall, Hydraulic Fracturing: If Fractures Cross Property Lines, Is There an Actionable Subsurface Trespass?, 54 NAT. RESOURCES J. 361 (2014).

93. Anderson, Subsurface "Trespass," supra note 12, at 247.

94. Id.

95. Id. at 248 .

96. Id.

97. Anderson, Lord Coke, supra note 12, at 203-04 (internal citations omitted).

98. See Calabresi \& Melamed, supra note 7, at 1089.

99. Anderson, Subsurface "Trespass," supra note 12, at 248 (citing as an artificial barrier N.D. CENT. CODE $\S 42-02-12$ (2009), which immunizes activities expressly authorized by law from being nuisances). 
tool in resolving subsurface-use disputes. ${ }^{100}$ In support he cites the oftquoted passage from Prosser and Keeton on Torts, which describing nuisance law as an "impenetrable jungle." "101 He also references certain artificial barriers several jurisdictions have raised to nuisance claims.

The substance of Anderson's brief critique of nuisance law, however, appears to be a preference for a strict liability standard: "[W]hen one intentionally injects a substance that physically invades the subsurface of a neighboring landowner, money damages should be recoverable for any actual and substantial damage caused without having to engage in the uncertainty of balancing whether the gravity of harm to the landowner outweighs the utility of the defendant's conduct." 102 The discussion below will evaluate the merits of a strict-liability approach like Professor Anderson's. ${ }^{103}$

\section{Focusing on Correlative Rights: Reservoir Community Analysis}

The alternative model of analyzing disputes over common subsurface property is Professor David Pierce's "reservoir community analysis." 104 Pierce's analysis focuses on the physical interconnectedness of common reservoirs rather than the artificial legal boundaries separating tracts of property at the surface. ${ }^{105}$ Reservoir community analysis "defines the rights and obligations of the owners in the oil and gas reservoir by recognizing that the owners coexist in a common environment instead of the artificial compartmentalized environment" created under a strict application of ad coelum. ${ }^{106}$ This mode of analysis would resolve intrareservoir disputes, like intrusions from hydraulic fracturing, by balancing the positive and negative correlative rights of the interest owners competing for exclusive control of the subsurface. ${ }^{107}$

100. Id.

101. $I d$

102. Id

103. See infra text accompanying notes 181-88.

104. David E. Pierce, Employing a Reservoir Community Analysis to Define and Marshal Correlative Rights in the Oil and Gas Reservoir, 76 LA. L. REV. 787 (2016) [hereinafter Pierce, Employing a Reservoir Community Analysis].

105. See generally, e.g., Pierce, supra note 43; David E. Pierce, Carol Rose Comes to the Oil Patch: Modern Property Analysis Applied to Modern Reservoir Problems, 19 PA. ST. ENVTL. L. REV. 241 (2011) [hereinafter Pierce, Carol Rose]; David E. Pierce, Developing a Correlative Rights Doctrine to Accommodate Development of Oil and Gas in Arkansas, 68 ARK. L. REV. 407 (2015); Pierce, Employing a Reservoir Community Analysis, supra note 104.

106. Pierce, Carol Rose, supra note 105, at 242.

107. Pierce, Employing Reservoir Community Analysis, supra note 104, at 795-96. 
Professor Tara Righetti has applied reservoir community analysis to intrareservoir disputes in the context of CCS. ${ }^{108}$ Under Righetti's analysis, "rather than focusing on the creation or abolishment of property rights in the subsurface, the application of correlative rights reframes the interests in the CCS 'storage complex' as a form of 'limited common property' wherein possessive rights are more appropriately allocated according to principles of proportionate use and enjoyment." ${ }^{109}$ Limited common property is described by Professor Carol Rose as an intermediate stage between fully public and fully private property in which property is held in common by members of a particular group - a "reservoir community" in Pierce's model-but is held by the group to the exclusion of all others. ${ }^{110}$

Although a full discussion of the relationship between nuisance and correlative rights doctrine, limited common property, and reservoir community analysis exceeds the scope of this Article, it is submitted that one can view nuisance as the tort-law counterpart of the property-law doctrine of correlative rights. ${ }^{111}$ As the tort of trespass protects against invasions of possessory property rights, the tort of nuisance protects against invasions of correlative property rights.

\section{NUISANCE AS AN ALTERNATIVE TO SUBSURFACE TRESPASS}

As this Part details, nuisance is a more context-sensitive model of governance than the exclusionary rule of trespass and therefore is better suited for coordinating conflicting uses of interconnected subsurface property. ${ }^{112}$ By applying nuisance, courts would have greater flexibility in tailoring efficient and equitable remedies when an unjustifiable

108. Righetti, supra note 10 , at 10420.

109. Id. at 10433 (citing Carol Rose, The Several Futures of Property: Of Cyberspace and Folk Tales, Emission Trades and Ecosystems, 83 MiNN. L. REV. 129, 132 (1998)) (emphasis added).

110. Carol Rose, Energy \& Efficiency in the Realignment of Water Rights, 19 J. LEGAL STUD. 261 (1990). As Rose has noted, effective administration of limited common property, in which owners' rights are correlative, often requires active regulation by a state actor. Carol Rose, The Comedy of the Commons: Custom, Commerce, \& Inherently Public Property, 53 U. CHI. L. REV. 711, 719-20 (1986); see also Hall, supra note 92, at 363, 406 (arguing that adoption of a "modern" trespass rule privilege subsurface interferences would lead to waste of underground resources absent close regulation by conservation authorities).

111. See generally Jeff L. Lewin, Boomer \& the American Law of Nuisance: Past, Present, \& Future, 54 ALB. L. REV. 189, 199 n.65 (1990) (discussing the evolution of the correlative rights doctrine from the predominate nineteenth century view of property as a natural right and noting the correlative rights "compromise" eventually failed, leading to the positivist view of property enshrined in the Restatement of Torts).

112. See Louis Kaplow, Rules Versus Standards: An Economic Analysis, 42 DuKE L. REV. 557, 559-60 nn.2-4 (1992) (explaining the distinction between standards and rules as the extent to which "efforts to give content to the law are undertaken before [(rules)] or after [(standards)] the act"). 
interference occurs. Application of nuisance would allow courts to temper harsh outcomes that might result under strict liability. One indication that nuisance is the appropriate remedy for subsurface property invasions is that, despite speaking in terms of trespass, courts already apply nuisance principles to resolve such cases. A review of the cases ${ }^{113}$ demonstrates that nuisance is already the de facto tort regime for subsurface interferences. It could only improve the clarity and consistency of courts' treatment of these cases to expressly articulate the principles that implicitly guide decisions.

\section{A. Nuisance Law: A Jungle No More}

The aim of nuisance law "is to achieve efficient and equitable solutions to problems created by discordant land uses." 114 Fundamentally, the law of nuisance mediates between two conflicting rights: "property owners have a right to control their land and use it to benefit their best interests, while the public and neighboring land owners have a right to prevent unreasonable use which substantially impairs the peaceful use and enjoyment of other land." 115 Paradigmatic nuisance cases involve suits to enjoin or recover damages caused by the negative externalities of otherwise socially valuable activities, such as stenches and fumes emitted from landfills, ${ }^{116}$ sewage treatment plants, ${ }^{117}$ agricultural activities, ${ }^{118}$ or industrial facilities like cement plants. ${ }^{119}$ Nuisance liability attaches for unjustified interference with the use and enjoyment of the plaintiff's land regardless of whether the plaintiff's right to exclude the defendant has been infringed.

\section{See infra Part IV.}

114. 66 C.J.S. Nuisances $\S 1$ (2019); see also Carroll v. Absolute Tank Removal, LLC, 834 A.2d 823,824 (Conn. Super. Ct. 2003) ("Historically, private nuisance law has been used 'as a means of efficiently resolving conflicts between neighboring, contemporaneous land uses. All of the very useful and sophisticated economic analyses of private nuisance remedies published in recent years proceed on the basis that the goal of nuisance law is to achieve efficient and equitable solutions to problems created by discordant land uses."”).

115. 66 C.J.S. Nuisances $\S 1$ (emphasis added).

116. E.g., Miller v. Jasniski, 705 S.W.2d 442 (Ark. Ct. App. 1986).

117. E.g., Adams v. Ark. City, 362 P.2d 829 (Kan. 1961). In water or sewage back-up cases liability usually lies in both nuisance and trespass. It is telling that a single occurrence can give rise to both torts. Trespass and nuisance are not mutually exclusive because they are causes of action for interference with distinct property interests-possession and use, respectively. See William L. Prosser, Nuisance Without Fault, 20 TEX. L. REV. 399, 414 (1942).

118. One early leading nuisance decision, for example, involved an action on the case for nuisance against the defendant for constructing a hog sty near the plaintiff's house. William Aldred's Case [1610], 77 Eng. Rep. 816, 9 Coke Rep. 57b.

119. E.g., Boomer v. Atl. Cement Co., 257 N.E.2d 870 (N.Y. 1970). 
Characterizations of nuisance as a "jungle" focus primarily on the tort's admittedly tangled history. ${ }^{120}$ According to Prosser, nuisance was long used as "a sort of legal garbage can" and a "substitute for any thought about a problem." 121 Prosser summarized the history of nuisance as follows:

The uncertainty has been due largely to the series of historical accidents by which nuisance came to cover the invasion of different, and unrelated, kinds of interests and to refer to various kinds of conduct on the part of the defendant. The word first appears in connection with interferences with servitudes or other rights to the free use of land. There was an old criminal writ (the assize of nuisance), affording incidental civil relief, which was designed to cover invasions of the plaintiff's land due to conduct wholly on the land of the defendant. In time this was supplanted by the more convenient action on the case for nuisance, which was limited strictly to interference with the use or enjoyment of land. ${ }^{122}$

Other commentators explain that, in its earliest form in the English legal system, nuisance was brought under a distinct common law writ. By the late fourteenth century lawyers largely abandoned the old writ and started suing under the newly recognized cause of action for trespass on the case, which often proved more strategic and convenient. ${ }^{123}$ The eventual elimination of the forms of action allowed courts and scholars flexibility to reimagine tort doctrine in general. ${ }^{124}$ According to Professor Dobbs, understanding of nuisance law became clearer following abolition as people grasped, first, that public and statutory nuisance cases should be analyzed separately from private nuisances and, second, that "private nuisance does not describe any particular conduct of the defendant, but a type of harm suffered by the plaintiff-impaired enjoyment of rights in land." 125

Much of this clarification was accomplished in the Restatement of Torts. The Restatement defined private nuisance as a tort based on the nature of the interest invaded rather than the nature of the conduct giving rise to the invasion. ${ }^{126}$ One observer observed that it recast nuisance law

120. DAn B. Dobbs ET AL., The LAW OF Torts $\S 398$ (2d ed. 2018). For an excellent and thorough history of the development of nuisance law, see Lewin, supra note 111, at 192.

121. Prosser, supra note 117 , at 410 .

122. Id. at 410-11; see also Lewin, supra note 111 , at 192.

123. Dillard et al., supra note 68, at 450-53; see also Ball, supra note 68 , at 652.

124. Dillard et al., supra note 68 , at 450-53.

125. DoBBS ET AL., supra note 120, $\$ 398$ (emphasis added).

126. RESTATEMENT (FIRST) OF TORTS ch. 40, at 218-20 (AM. LAW INST. 1939). 
as a "utilitarian calculus in which property rights were defined with the aim of achieving the greatest social good. By the Restatement's definition, private nuisance is any claim involving "a non-trespassory invasion of another's interest in the private use and enjoyment in land," ${ }^{27}$ further clarifying that "nuisance" describes the property right that is injured rather than the condition that causes injury. Actionable invasions could be either intentional and unreasonable or unintentional and otherwise actionable under other torts like negligence or strict liability for ultrahazardous conduct.

Section 826 defined "unreasonable" conduct by quantitatively weighing the "utility of the actor's conduct" against "the gravity of harm" in what came to be known as the "balance of utilities test." 128 Under the test, conduct that damages another's interest in the use of her land may be conducted without liability if its social utility is sufficiently great to justify the harm done. This was not a new concept in the law; it had previously been expressed as balancing the parties' respective interests as opposed to the utility of their respective uses. ${ }^{129}$

\section{B. The Restatement (Second)'s Approach to Nuisance}

The Restatement (Second) of Torts retains the cost-benefit calculation embodied in the balance of utilities test but was amended to account for a large number of cases imposing strict liability for conduct that was not characterized as ultrahazardous or abnormally dangerous. ${ }^{130}$ The amendment resulted in the addition of section 829A, which imposes liability where an invasion is so substantial that the plaintiff should not be compelled to suffer it without compensation even if the defendant is without fault and the conduct is not abnormally dangerous.

While many courts apply a nuisance doctrine similar to that articulated in the Restatement (Second), not as many have expressly adopted the entirety of the Restatement (Second). ${ }^{131}$ Given the diversity in private nuisance law across jurisdictions, however, the discussion in the remainder of this Article will refer to the Restatement (Second) as the

127. ReStatement (SECOND) OF ToRTS $\S 821$ D (Am. LAW InSt. 1965) (emphasis added).

128. Id. § 826(a); see also Lewin, supra note 111, at 211.

129. Comment a to section 826 of the Restatement (Second) cites an early case involving candlemaking where it was found there was no public nuisance because "[1]e utility del chose excusera le noisomeness del stink." $I d$. $\S 826 \mathrm{cmt}$. a (citing STEPHEN, GENERAL VIEW OF THE CRIMINAL LAW OF ENGLAND $106(1890)$ ).

130. See Lewin, supra note 111, at 222.

131. See id. at 234-35. 
generic standard. ${ }^{132}$ The following outline of its essential provisions will thus aid the subsequent discussion.

Section 822 defines a private nuisance as a legal cause of invasion of another's interest in the private use and enjoyment of land that is (a) intentional and unreasonable, or (b) unintentional and otherwise actionable as negligence, recklessness, or strict liability for abnormally dangerous activities. ${ }^{133}$ Sections 826 through 831 contain standards for determining when an invasion is "unreasonable" under 822(a). Section 826 instructs that an invasion is unreasonable if (a) the gravity of the harm outweighs the utility of the conduct (i.e., the balance of utilities test), or (b) the harm caused by the conduct is "serious" and the financial burden of compensating for this and similar harm to others would not make the continuation of the conduct infeasible. ${ }^{134}$

Under section 826 the utility of an activity is not weighed in a vacuum but is evaluated with reference to what is done about its consequences. Hence a cement plant's "utility" would be greater if it pays compensation to its neighbors for harm done than if it does not. ${ }^{135}$ Under subsection (b), conduct is "unreasonable" even if its utility outweighs the gravity of harm caused if the harm is "serious" and it would not render the conduct infeasible to continue if compensation were awarded. ${ }^{136}$ If the burden of making compensation would potentially put the conduct out of business, courts conduct a weighing process as it would occur in a claim for injunction. ${ }^{137}$

The gravity of the harm is determined under section 827 based on the following factors: (a) the extent of the harm; (b) the character of the harm; (c) the social value of the use invaded; (d) the suitability of the use invaded to the character of the locality; and (e) the burden of the person harmed in avoiding the harm. ${ }^{138}$ The utility of conduct is determined under section 828 based on similar factors: (a) social value of the conduct; (b) suitability of the conduct to the character of locality; and (c) impracticability of avoiding the invasion. ${ }^{139}$

132. This Article's use of the Restatement (Second) as the standard for nuisance doctrine is not intended as an endorsement of its utility-balancing approach, which has been subjected to powerful criticism. See, e.g., Richard A. Epstein, Nuisance Law: Corrective Justice and Its Utilitarian Constraints, 8 J. LEGAL STUD. 49 (1979) (criticizing utilitarian approaches to defining property rights and nuisance law).

133. RESTATEMENT (SECOND) OF TORTS $\S 822$ (AM. LAW INST. 1965).

134. Id. $\S 826$.

135. Id. $\S 826 \mathrm{cmt}$. e.

136. Id. $\S 826(\mathrm{~b})$.

137. Id. $\S 826 \mathrm{cmt}$. f.

138. Id. $\S 827$.

139. Id. $\S 828$. 
Section 831 deems conduct to be unreasonable if it is unsuited to the character of the locality and causes significant harm to a use that is well suited to the locality. ${ }^{140}$ Finally section $829 \mathrm{~A}$ incorporates the compensation principle, noted above, by deeming otherwise justifiable conduct unreasonable "if the harm resulting from the invasion is severe and greater than the other should be required to bear without compensation." 141

\section{The Nonpossessory Nature of Subsurface Property Intrusions}

Courts often conflate trespass with nuisance, labelling conduct a "trespass" but applying nuisance standards to resolve it. ${ }^{142}$ Indeed trespass and nuisance border each other and can both arise from one incident. ${ }^{143}$ But trespass and nuisance are distinct because they exist to protect different property rights. One act can occasion both an invasion of another's right of possession (a trespass) and her right of reasonable use and enjoyment (a nuisance). It follows that only owners whose property interests are possessory may sue for trespass. ${ }^{144}$ While courts have not explicitly classified subsurface property as possessory or nonpossessory, as Professor Righetti notes, this classification "may prove dispositive as to the remedies available to owners for subsurface intrusions." 145 Consequently, in distinguishing trespass and nuisance as alternative tort remedies for invasions of subsurface property, it is essential to first examine, as the following section does, whether subsurface property is possessory or nonpossessory.

140. Id. $\S 831$.

141. Id. § 829A. Per Professor Lewin,

Any inquiry by a court should start with section $829 \mathrm{~A}$, for if the harm is sufficiently 'severe,' the plaintiff is entitled to compensation in damages regardless of the utility of the defendant's activity and regardless of whether damage liability would cause the defendant to cease the activity. If the damage is not sufficiently 'severe' to trigger section 829A, it may nevertheless be 'serious' enough to warrant compensation under section $826(\mathrm{~b})$ without regard to the utility of the defendant's activity, but only if damage liability would not cause the defendant to cease the activity. Finally, if the plaintiff's damages were not severe enough to warrant compensation under section 829A and the plaintiff was not entitled to compensation under section 826(b) either because the damages were not sufficiently serious or because damage liability would cause cessation of the activity - the plaintiff might still be entitled to compensation (as well as an injunction) under the balance of utilities test.

Lewin, supra note 111, at 227.

142. DOBBS ET AL., supra note $120, \S 399$.

143. See DOBBS ET AL., supra note 120, §399; Reynolds, supra note 66, at 228.

144. See Kulander \& Shaw, supra note 44, at 70 (collecting cases); Louise A. Halper, Nuisance, Courts and Markets in the New York Court of Appeal, 1850-1915, 54 ALB. L. REV. 301, 341-42 (1990) (discussing nuisance as the traditional cause of action to remedy injuries to nonpossessory property interests).

145. Righetti, supra note 10 , at 10428-29. 


\section{What Is "Possession"?}

The root of all title to property at common law is first possession. ${ }^{146}$ Possession grants the possessor the right to exclude others from the thing possessed. To modern theorists, possession is the sina qua non of property. As Professor Thomas Merrill explains, "Give someone the right to exclude others from a valued resource, i.e., a resource that is scarce relative to the human demand for it, and you give them property. Deny someone the exclusion right and they do not have property." 147 All other rights associated with ownership of property, according to Professor Merrill, derive from and depend on the right to exclude.

Carol Rose has identified two "great principles" defining the meaning of "possession": "(1) notice to the world of a claim to property through a clear act, and (2) reward to useful labor." 148 The rationale of granting possession to reward useful labor is subsumed in Rose's first definition because application of useful labor to a thing is itself an act giving notice to the world. ${ }^{149}$ To Rose, possession is a kind of statement communicating the speaker's claim over a thing to an audience comprised of all others who might be interested in claiming the thing themselves. The purpose of the statement is to establish the right to exclude. Dean Wigmore defines possession of real property similarly: "Possession is a relation of control of a thing as against other persons. A possession consists of two elements, with reference to the area deemed to be possessed, (a) the area actually controlled against others by the bodily force of the person; [and] (b) the area willed by him to be included in his potential control, as expressed in his acts of will." 150 To Wigmore the "potential control" appears to be tantamount to constructive possession and stretches as far as the possessor is able to indicate through acts of expression.

Legal rules designate the types of statements that constitute notice of an exclusive claim to the relevant audience. ${ }^{151}$ Possession of the surface area of real property is usually marked by fences or cultivation, or constructively by legal descriptions in deeds. ${ }^{152}$ Once established, possession can be lost by failing to communicate the claim continually

146. Richard Epstein, Possession as the Root of Title, 13 GA. L. REV. 1221 (1979); Rose, supra note 62 , at 75 .

147. Merrill, supra note 62, at 730 .

148. Rose, supra note 62 , at $77-78,83$.

149. Id.

150. 2 JOHN HENRY WigMORE, SELECT CASES ON THE LAW OF TORTS WITH NOTES \& A SUMMARY OF PRINCIPLES app'x A, $\S 118$ (1912).

151. Rose, supra note 62 , at $87-88$. To establish claims to objects of nature, like land, the law has designated the statements of "cultivation, manufacture, and development." Id.

152. WIGMORE, supra note 150, app'x A, § 118. 
and allowing another to invade the object and communicate a superior claim. ${ }^{153}$ Possessors must guard against such invaders, which they can do either through self-help ejectment or an action for trespass. ${ }^{154}$

Some things, like easements, ${ }^{155}$ are inherently incapable of clear demarcation and thus of possession. Claims to these things are established only through systems of secondary demarcation like land records. ${ }^{156}$ Other things, like the airspace above land, are often said to be capable only of limited or "effective possession." 157 An early twentieth century commentator noted that under this view, "[a] man cannot own air in its free state; the rule is universal. A man may have an easement for light, or an easement for free access of air, or a right against the pollution of his air, but the air itself he cannot own." ${ }^{158}$ An early court explained the property interest in airspace likewise, stating, "[i]t would be vain to treat property in airspace upon the same footing as property which can be seized, touched, occupied, handled, cultivated, built upon and utilized in every feature." 159 Thus, authorities tend to speak of the surface owner as possessing the airspace above her land only as far as it is necessary to support her use and enjoyment of the land. ${ }^{160}$

\section{Is the Subsurface Property Interest Possessory?}

Like airspace, the deep subsurface cannot be seized, touched, or utilized as readily as the surface of land. Unlike airspace, the deep subsurface is impossible to efficiently demarcate through use or development as to communicate an exclusive claim, except indirectly

153. Rose, supra note 62 , at $78-79,81$.

154. These legal actions were originally intended to avoid breaches of the peace that often accompany the alternative remedy of self-help. Bohlen, supra note 72, at 318-19, 19 n.19; Henry E. Smith, Self-Help \& the Nature of Property, 1 J.L. ECON. \& POL'Y 69, 81-86 (2005).

155. Black's Law Dictionary defines an "easement" as, "[a]n interest in land owned by another person, consisting in the right to use or control the land, or an area above or below it, for a specific limited purpose (such as to cross it for access to a public road)." Easement, BLACK'S LAW DICTIONARY (9th ed. 2009).

156. Rose, supra note 62 , at 83.

157. Leo Jaffe, Air Law-Trespass by Airplane, 9 TEX. L. REV. 240, 243 (1931). The concept of "effective possession" was criticized widely by contemporary scholars for being obscure and "difficult of both definition and application." Ball, supra note 68, at 641-42.

158. Ball, supra note 68, at 632-33.

159. Smith v. New Eng. Aircraft Co., 170 N.E. 385, 390 (Mass. 1930).

160. See, e.g., United States v. Causby, 328 U.S. 256, 264 (1946) ("The landowner owns at least as much of the space above the ground as he can occupy or use in connection with the land."). The fact that courts view the airspace as only an effective possessory interest has played a role in the abandonment of trespass rules in favor of nuisance in airspace overflight cases. See Reynolds, supra note 66 , at $235-37$. 
through possession of the surface, because it is hidden from view. ${ }^{161}$ In addition, a pore space-owner has no practical means excluding others from invading its claimed pore space, except perhaps at great expense. ${ }^{162}$ Further, and perhaps more important, it is highly difficult even with expert evidence to monitor the subsurface to determine whether an invasion of pore space has occurred. ${ }^{163}$ Thus, although the substances contained within pore space may be deemed subject to possession while in place, ${ }^{164}$ the pore space itself is no more, and perhaps less, susceptible of possession than the airspace.

This last conclusion is loosely consistent with Dean Wigmore's view of subterranean land ownership. In Wigmore's conception a landowner can possess only the surface area. The surface includes certain "appurtenant rights" in subjacent and superjacent space. Per Wigmore, "The space subjacent to the land is included without limit as to distance downwards. The right in this aspect protects merely against an intrusion into the lower soil or a removal of it. But an act which causes the surface to fall is a violation of the main right." ${ }^{\text {165 }}$ The appurtenance Wigmore

161. See LOWE ET AL., supra note 1, at 163-64. As Lowe et al. explain, adverse possession requires open and notorious conduct for the statutory period in order to give notice of the adverse possessor's claim to the true owner. Hence, where the mineral estate has been severed prior to the beginning of an adverse possession, the possessor's use of the surface will not ripen into title to the mineral estate as well. Id.

162. FPL Farming Ltd. v. Envtl. Processing Sys., LC, 351 S.W.3d 306, 314 (Tex. 2011) ("Mineral owners can protect their interests from drainage through means such as pooling or drilling their own wells. This is not necessarily the case when a landowner is trying to protect his or her subsurface from migrating wastewater." (internal citations omitted)); see also Righetti, supra note 10, at 10428 ("Owners of pore space may develop their interest into a stronger possessory claim based on their use, and yet at any time prior to that use, they are also subject to dispossession by virtue of their neighbor's use."). It appears dispossession by a neighbor is equally possible after a subsurface owner "uses" her pore space because pore space "can be filled, emptied and refilled" at any time. See id.

163. See, e.g., Hill v. Sw. Energy Co., 858 F.3d 481, 485-87 (8th Cir. 2017) (reviewing district court's exclusion of expert testimony pertaining to the spread of injected "fracking waste"); Raymond v. Union Tex. Petroleum Corp., 697 F. Supp. 270, 272 n.7 (E.D. La. 1988) ("Considering the expert testimony in this case regarding the uncertainty of determining if, when, and where injected salt water might migrate, it is unlikely that an operator would undertake to execute leases with all landowners under whose property injected salt water might migrate."); Nunez v. Wainoco Oil \& Gas Co., 488 So.2d 955, 959 n.9 (La. 1986) ("Noting that the earth is round, we point out that a surface tract's subsurface measurement must necessarily narrow as it approaches the center point of the . . . boundaries as the available area diminishes. Just how much or how little plaintiff's subsurface ownership has narrowed at a depth of two miles is a peripheral question which, needless to say, will not be addressed in this opinion.”); Chance v. BP Chems., Inc., 670 N.E.2d 985, 993 (Ohio 1996) ("All of these and more disputed variables went into the construction of the hypothetical models that attempted to illustrate the lateral extent of the migration. Given all these variables, there were great difficulties in appellants' establishing, as a factual matter, that a property invasion had occurred, so that appellants' claim must be regarded as somewhat speculative.").

164. Some states characterize interests in minerals, such as oil and gas, in place, before production, as possessory and others do not. See MARTIN ET AL., supra note 1, at 17-75 (discussing mineral ownership theories across jurisdictions).

165. 2 WigMORE, supra note 150, app'x A, § 104. 
describes is negative in nature. It is a right to be free from conditions in superjacent and subjacent space that diminish the surface area's habitability or availability for economic use. ${ }^{166}$ Wigmore's appurtenances are probably classifiable as incorporeal hereditaments-nonpossessory rights attached to ownership of land ${ }^{167}$ Doctrinally, after the writ system, the only tort generally available to remedy an invasion of a nonpossessory interest in real property is nuisance; trespass is not available where there is no violation of a right to exclude. ${ }^{168}$

It should be no surprise then that, while purporting to apply trespass, courts in subsurface invasion cases apply nuisance-like standards. One inference to draw from these cases is that the owner of a fee interest in real property owns a nonpossessory interest in the subsurface strata, along the lines of Dean Wigmore's subterranean appurtenance. Invasions of the subsurface interest are, consequently, nontrespassory. They are nuisances.

\section{COURTS' NONTRESPASSORY TREATMENT OF INVASIONS OF SUBSURFACE PROPERTY INTERESTS}

Courts have been hesitant to consider the possessory or nonpossessory nature of a property interest in subsurface land. ${ }^{169}$ Regardless whether or not a fee interest in surface property entitles the owner to a possessory interest in the subjacent rock and pore space, a review of subsurface invasion cases reveals that courts resolve unauthorized intrusions into these things as nontrespassory invasions. Despite calling them subsurface "trespasses," courts treat these intrusions as implicating only use-and not possession - of the rock or pore space. ${ }^{170}$ The clearest indication that courts are concerned with use, as opposed to possession, is their

166. Id. $\S \S 101-102,104$. Professor Louise A. Halper notes a similar type of property interest that developed as the need to protect owners of property adjacent to the then-newly constructed elevated railway in New York City became acute. According to Halper, courts expanded their recognition of property interests to include an "interest [appurtenant to land] in being free from injury . . . in the form of a limited easement; limited in that the [owner] could do nothing with the easement except market it." Halper, supra note 144 , at 344.

167. Incorporeal Hereditament, BLACK's LAW DICTIONARY (9th ed. 2009).

168. See supra section I.A.

169. E.g., Martel v. Hall Oil Co., 253 P. 862, 867 (Wyo. 1927) ("We have already stated that there was a technical violation of the rights of the plaintiff. We need not determine what sort of an estate plaintiffs had in the land.").

170. Professors Keeton and Jones seem to have identified this phenomenon among Texas's preGarza hydraulic fracturing cases. See Keeton \& Jones, supra note 71, at 267 ("The invasions in these cases are both direct and intentional, and unless it can be said that there is no interference with possession either because of some distinction between surface and subsurface invasions or because the water and the sand particles in solution do not constitute the type of 'thing' that is sufficient to constitute a legal interference with possession, there would seem to be a technical trespass and a use of another's property. Technically, it is not the fracturing of the formation that would constitute the trespass but rather the intrusion into the formation of the sand and water."). 
application of legal standards and remedies associated with nuisance, as opposed to trespass. ${ }^{171}$ Courts generally impose a liability rule that entitles the affected owner to damages but no injunction. This holds across jurisdictions and types of conduct, including waste disposal, enhanced oil recovery, natural gas storage, directional drilling, and hydraulic fracturing. The remainder of this section surveys cases arising in each context to illustrate that a consensus of courts analyzes subsurface intrusions as nontrespassory nuisances. The final section discusses how a nuisance analysis could apply to resolve subsurface interferences arising from CCS and other emerging technologies.

\section{A. Waste Disposal Cases}

The primary waste associated with oil and gas production by volume is produced water. Produced water is the brine originally trapped in reservoirs that is brought to the surface in oil and gas extraction. ${ }^{172}$ Best practice in modern oil and gas production is to dispose of produced water by injection into geologic reservoirs. Saltwater disposal wells are permitted under the federal Underground Injection Control (UIC) program, ${ }^{173}$ as are several other classes of injection wells, including those for hazardous and nonhazardous fluid wastes. ${ }^{174}$ To obtain administrative injection authority under the UIC program, operators must have the consent of the owner of the surface interest in the tract where the well is to be located. UIC wells are thus typically permitted on relatively small tracts of land in comparison with the subsurface area in which the injected fluids migrate over time.

Disputes arise when fluid injected in a UIC well crosses the boundaries of the tract where the well is permitted and into the subsurface pore space of neighboring owners without their consent. The key question in these cases tends to be "whether the owner has a right of recovery on a trespass theory for the unauthorized invasion and use of the space underneath the

171. "Trespass" as used here refers to traditional trespass quare clausum fregit. It should be noted that courts appear to treat claims for subsurface invasions as claims for trespass on the case. This explains the requirement most courts impose on plaintiffs to show actual injury to use or enjoyment of the property and the infrequency of injunctive relief.

172. See Nat. Res. Def. Council v. U.S. Envtl. Prot. Agency, 863 F.2d 1420, 1425 (9th Cir. 1988) (describing produced water).

173. 42 U.S.C. $\S \S 300 f-300 j-26$ (Supp. 2012). Subject to federal oversight, the UIC program is primarily administered by individual states. Id. $\S 300 \mathrm{~h}$.

174. These are Class I wells, which inject hazardous and nonhazardous wastes; Class II wells, which inject produced water; Class III wells, which inject fluids to dissolve and extract minerals; Class IV wells, which inject hazardous or radioactive waste in shallow geologic reservoirs; Class V wells, which inject nonhazardous waste into shallow geologic reservoirs; and Class VI wells, which inject $\mathrm{CO}_{2}$ for geologic sequestration. 40 C.F.R. $§ 144.6$ (2019). 
surface," even if no physical damage or interference with the owner's use or enjoyment of the property occurred as a result. ${ }^{175}$ The issue arises because, given the complexity of predicting where injected fluid could migrate, it is unlikely any lessee would ever attempt to get the consent of all owners whose land the fluid might migrate. ${ }^{176}$ This is also the principal question surrounding liability for migration of sequestered $\mathrm{CO}_{2}$.

As will be seen in the following review of cases, an owner generally does not have a right to recovery on a true trespass theory for the unauthorized invasion and use of the space under her surface property. Although courts label such claims as "trespasses," they tend to eschew applying any of the rules or remedies traditionally associated with trespass. Instead, they require a showing of actual harm in addition to the fact of the unauthorized invasion and deny ejectment and nominal damages as remedies. Moreover, courts frequently reference the social value of the injector's activity and weigh it against the severity of the harm sustained by the plaintiff. Such departures from the traditional tort render these decisions unrecognizable as trespass cases. Rather, the typical analysis in fluid injection cases closely resembles the tort of nuisance. Reviewing these cases, it is clear that the strict, possession-protecting provisions of trespass are inapplicable to property interests in the subsurface, but that the flexible, use-accommodating precepts of nuisance are appropriate.

In FPL Farming, Ltd. v. Texas Natural Resources Conservation Commission, ${ }^{177}$ for example, the Texas Court of Appeals required a showing of actual harm to establish liability for "trespass" from the unauthorized invasion of injected wastewater. FPL Farming, Ltd. (FPL Farming) appealed the commission's order granting two injection well permits allowing Environmental Processing Systems, L.P. (EPS) to inject nonhazardous wastewater into a deep subsurface saltwater formation. ${ }^{178}$ It was projected that the injected wastewater would enter under neighboring land owned by FPL Farming within ten years of initial injection. ${ }^{179}$ FPL Farming challenged the injection permits, contending that granting the permits exceeded the commission's statutory authority and constituted an unconstitutional taking of FPL Farming's property without compensation.

"Assuming without deciding that FPL Farming has 'existing rights' in the deep subsurface beneath its land," the court affirmed the commission's

175. Keeton \& Jones, supra note 71 , at 268.

176. Raymond v. Union Tex. Petroleum Corp., 697 F. Supp. 270, 272 n.7 (E.D. La. 1988).

177. No. 03-02-00477-CV, 2003 WL 247183, at*1 (Tex. Ct. App. Feb. 6, 2003).

178. Id.

179. Id. 
finding that the injection would not impair any existing legal rights. ${ }^{180}$ The court elaborated, "In essence, FPL Farming argues that migration [of wastewater] alone will impair FPL Farming's existing rights. We disagree, concluding...that some measurement of harm must accompany the migration for there to be impairment." the court noted the commission's position that "property owners do not have the right to exclude deep subsurface migration of fluids." 182

FPL Farming also lost on its claim that the permits effected a physical taking by allowing the wastewater plume to occupy its subsurface. A physical taking occurs when the government authorizes a "physical occupation" of property. Under Loretto v. Teleprompter Manhattan CATV Corp., ${ }^{183}$ a physical occupation occurs when the government action "destroys three rights associated with the ownership of property: the power to possess, use, and dispose." 184 The FPL Farming Court was unpersuaded by FPL's argument that it "lost its right to possess the subsurface because the amended permits hamper its right to exclude EPS's waste plume, which is projected to migrate onto its property within the next ten years." 185 FPL's Loretto claim failed accordingly because it lacked possessory rights in the subsurface. ${ }^{186}$

Likewise, in Chance v. BP Chemicals, Inc. ${ }^{187}$ the Ohio Supreme Court defined the surface owner plaintiffs' pore space rights to include only "the right to exclude invasions of the subsurface property that actually interfere with [their] reasonable and foreseeable use of the subsurface." 188 In Chance, several landowners sued BP Chemicals for damages allegedly caused by lateral migration of hazardous byproducts injected at BP's nearby chemical refinery. ${ }^{189}$ The plaintiffs asserted several common law claims; the only issue that received significant discussion on appeal, however, was whether the trial court erred by requiring plaintiffs to show "some type of physical damages or interference with use" to establish a

180. Id. at *3.

181. Id. at $* 4$.

182. Id. at *3.

183. 458 U.S. 419,435 (1982).

184. FPL Farming, $2003 \mathrm{WL} 247183$, at *5 (citing Loretto v. Teleprompter Manhattan CATV Corp., 458 U.S. 419, 435 (1982)).

185. $I d$.

186. The result in FPL Farming is especially notable when viewed in light of the facts of Loretto itself. There the Court held that placement of small television cable on Loretto's five-story apartment building constituted a physical occupation of the plaintiff's property and an unconstitutional taking, noting, "the permanent physical occupation of property forever denies the owner any power to control the use of the property ...." Loretto, 458 U.S. at 436.

187. 670 N.E.2d 985 (Ohio 1996).

188. $I d$. at 992 (emphasis added).

189. Id. at 990. 
trespass. ${ }^{190}$ The plaintiffs argued that any unauthorized invasion of their subsurface would constitute trespass irrespective of actual interference with preexisting use because common law trespass presumes damage. ${ }^{191}$

Affirming the trial court, the Ohio Supreme Court found the incursion of hazardous waste did not violate the plaintiffs' interest in the subsurface. The court reasoned that the plaintiffs' right to possess the subsurface is limited in the same way a landowner's right to possess the sky is limited under Causby, for instance, only to the extent of the owner's existing or foreseeable use. ${ }^{192}$ Applying Chance in a gas storage case, the Northern District of Ohio in Baatz v. Columbia Gas Transmission, $L L C^{193}$ put a finer point on the rule in this way:

If a landowner's right to exclude a subsurface invader is limited to those portions of the subsurface the landowner actually uses or foreseeably may use, then Chance should also stand for the converse proposition that one has no right to exclude a subsurface 'invader' from portions of the subsurface that one does not use. ${ }^{194}$

The Sixth Circuit's subsequent opinion affirming Baatz refined the rule once more: "[T] he Landowners do not have a 'reasonable and foreseeable use' of their subsurface. As such, the Landowners do not have a present possessory interest in their subsurface ...."195

A recent Texas Court of Appeals Case, Swift Energy Operating, LLC v. Regency Field Services, $L L C,{ }^{196}$ demonstrates that Texas courts view subsurface invasions as actionable only when they interfere with an owner's use and enjoyment. Swift sued Regency for trespass when Regency's injected waste gas migrated under Swift's lease. The parties disputed on what date the two-year limitations period accrued on Swift's trespass claim. ${ }^{197}$ Regency asserted on summary judgment that Swift's trespass claims accrued when the injectate entered Swift's leases. Swift countered that no cause of action accrued "merely because of the uninvited intrusion of injectate into the subsurface space covered by" Swift's leases, ${ }^{198}$ and argued instead that any claim arose only when the

\footnotetext{
190. Id. at 993.

191. Id. at 993.

192. Id. at 992 (internal quotation marks omitted) (quoting Vill. of Willoughby Hills v. Corrigan, 278 N.E.2d 658, 665 (Ohio 1972)).

193. 295 F. Supp. 3d 776 (N.D. Ohio 2018), aff'd, 929 F.3d 767 (6th Cir. 2019).

194. Id. at 785.

195. Baatz v. Columbia Gas Transmission, LLC, 929 F.3d 767, 777 (6th Cir. 2019).

196. No. 04-17-00638-CV, 2019 WL 1547608 (Tex. Ct. App. Apr. 10, 2019).

197. Id. at *3-4.

198. Id. at*3 (Swift cited Lightning Oil Co. v. Anadarko E\&P Onshore, LLC, 520 S.W.3d 39 (Tex. 2017), discussed infra in the text accompanying notes 280-292).
} 
injectate "actually infringe[d] on [Swift's] mineral rights." 199 The appellate panel sided with Swift finding the cause of action accrued only because "the injected plume overlaid Swift's leased depths and would require Swift to drill any new wells through the contamination, and the injectate had reached Swift's existing well bores and would corrode them," and thus affected Swift's rights in the mineral lease. ${ }^{200}$ In other words, the mere incursion of unauthorized substances did not implicate Swift's rights in the subsurface and therefore the incursion must have been nontrespassory.

Similarly, in Raymond v. Union Texas Petroleum Corp. ${ }^{201}$ the Eastern District of Louisiana found "no legally actionable trespass" for migration into the plaintiffs' subsurface of saltwater injected on adjoining land. ${ }^{202}$ The plaintiffs sought damages for trespass measured by the rental value of the pore space occupied by the wastewater. Although the claim failed for other reasons, the court commented there would be no actionable trespass even if the plaintiffs could prove the invading water was unauthorized because they suffered no "injury or inconvenience" and ownership rights are limited as necessary to prevent waste of hydrocarbons and needless drilling. ${ }^{203}$

199. Swift Energy Operating, LLC, 2019 WL 1547608 at*3.

200. Id. at $* 4$.

201. 697 F. Supp. 270 (E.D. La. 1988).

202. Id. at 273.

203. Id. at 273-75 (citing Nunez v. Wainoco Oil \& Gas Co., 488 So. 2 d 955 (La. 1986) and W. Edmond Salt Water Disposal Ass'n v. Rosecrans, 226 P.2d 965 (Okla. 1950)); see also Jefferson Island Storage \& Hub, LLC, 255 F.3d 271, 275 (5th Cir. 2001) ("If saltwater injected by Jefferson Island did migrate beneath the Boudreaux plaintiffs' property a mile underground, that fluid did nothing more than displace existing saltwater and in no way affected the use or enjoyment of the land."). The Kansas Supreme Court applied a similar analysis in Crawford v. Hrabe, in which the court wrote,

While our discussion of trespass cases is helpful, it is not conclusive. We turn to consideration of the economics and practical usage of salt water disposal or other water in a secondary recovery operation. . . . In the final analysis our decision must . . . be driven by the facts of this particular case. The secondary recovery operations have increased production. This increase is beneficial to all parties. Off-lease salt water is economically available. To drill a supply well on the Hrabe property would increase expenses of lease operations. 44 P.3d 442, 452 (Kan. 2002). Texas courts do not, as the Crawford Court did, conflate the social value of saltwater disposal with the value of injection for enhanced oil recovery. The Texas Supreme Court has stated that injecting substances to aid in the extraction of minerals serves a different purpose than does injecting wastewater. We have recognized that '[i]t cannot be disputed that [secondary operations to recover oil and gas] should be encouraged' to 'increase the ultimate recovery of oil and gas' .... Manziel and Garza considered the justification for the rule of capture-greater oil and gas recovery - in their analyses. However, the rule of capture is not applicable to wastewater injection. Mineral owners can protect their interests from drainage through means such as pooling or drilling their own wells. FPL Farming Ltd. v. Envtl. Processing Sys., L.C., 351 S.W. 3d 306, 314 (Tex. 2011) (internal citations omitted). 
The courts in the above cases did not award damages for fluid invasions. When they do award damages for fluid migration courts tend to be unclear about the doctrinal basis for the award. In Cassinos v. Union Oil Co. of California, ${ }^{204}$ for example, the California Court of Appeals affirmed an award of damages to a mineral interest owner based on the oil and gas lessee's injection of off-lease produced water. ${ }^{205}$ The lessee injected the water into a well on the mineral owner's lease with the permission of the surface interest owner and the injection interfered with existing oil production from the lease. The court noted that in California the mineral estate is nonpossessory and mineral owners enjoy merely an exclusive right to take minerals in place, otherwise classified as a profità-prendre. Purporting to apply this doctrine, Cassinos affirmed the trial court's award of damages and held that the injection constituted a "permanent trespass" of the mineral owner's nonpossessory interest. ${ }^{206}$

Cassinos's reasoning illustrates a pervasive problem in subsurface invasion cases. Even though the classification of a mineral estate in California (a nonpossessory profit-à-prendre) does not include possession rights, Cassinos held that interference with a mineral interest owner's ability to produce minerals constitutes a permanent trespass. This cannot be correct doctrinally unless "trespass" means trespass on the case. On the contrary, the property interest affected by the defendant's injection in Cassinos must have been the mineral owner's right to access and produce, i.e. use, the minerals. Infringement of the right to use interests in real property is a nuisance.

The error in Cassinos is not merely a labelling mistake. Labeling conduct a "trespass" incorporates a particular legal rule of liability and particular remedies that meaningfully differ from the legal standard and remedies that apply when conduct is labeled a "nuisance." When courts like Cassinos label subsurface invasions "trespasses," they often find that the rules and remedies for trespasses do not fit the circumstances or achieve desirable results. Courts then modify the rules of trespass to provide flexibility to accommodate the competing interests. As FPL Farming, Chance, and Cassinos illustrate, modifications include: (a) requiring proof of actual damages; (b) eliminating nominal damages and ejectment as remedies; and (c) weighing the plaintiff's injuries against the economic or social value of the defendant's injection to determine liability. Each of these modifications tend to morph the tort into nuisance, which, based on the nature of the property interest truly implicated, provides the appropriate analytical framework.

204. 18 Cal. Rptr. 2d 574 (Cal. Ct. App. 1993).

205. $I d$.

206. $I d$. at 582,584 . 
Oklahoma courts do apply a "modified" private nuisance doctrine to resolve subsurface invasions by injected fluid. ${ }^{207}$ Oklahoma's modified nuisance doctrine "is essentially the common law doctrine as altered by a provision in the Oklahoma Constitution which the Oklahoma courts have said removes the common law elements of carelessness or unreasonableness." ${ }^{208}$ Thus where a nuisance is found strict liability attaches. In determining whether conduct constitutes a nuisance, Oklahoma courts apply a reasonableness rule under which "a person may use his property in any lawful manner, except that he must not use it so as to injure or damage his neighbor." ${ }^{209}$ It is not clear what standards Oklahoma courts apply to determine the reasonableness of a given use. It can be observed, however, that no liability attaches in cases where only saltwater invades the plaintiff's land and the plaintiff can show no actual damages beyond the fact of the invasion. The opinions justify this result based on the importance of wastewater disposal to the industry and society. ${ }^{210}$

Where an invasion causes actual damage, Oklahoma courts award compensation regardless of any justification for the invasion. Courts have interpreted Oklahoma's constitution to contain a strict liability provision protecting a landowner against any losses "in the nature of real and substantial injury to his property, resulting from the use of adjacent or nearby property by its owner." ${ }^{211}$ In West Edmond Hunton Lime Unit $v$. Lillard ${ }^{212}$ for example, the plaintiff showed that injected saltwater from the defendant's operations precluded the plaintiff from producing and pulling the casing from a well on his property. Lillard awarded compensatory damages without considering reasonableness or social utility of the defendant's conduct. The court also did not consider whether the expense of paying compensation might render the defendant's injection operations infeasible.

These fluid disposal cases illustrate that courts conceive of subsurface property rights merely as use rights that do not entitle the owner to exclusively claim any portion of subsurface strata it is not presently, or foreseeably will be, using. The plaintiffs in FPL Farming, Chance, and Raymond did not show any injury to existing or foreseeable uses of the property and consequently were held not to have an actionable claim based on the invasion of their subsurface. The plaintiffs in Cassinos and

207. Greyhound Leasing \& Fin. Corp. v. Joiner City Unit, 444 F.2d 439, 441 (10th Cir. 1971).

208. Id.

209. W. Edmond Salt Water Disposal Ass'n v. Rosecrans, 226 P.2d 965, 973 (Okla. 1950).

210. See, e.g., id. at 969-71 (noting that if saltwater disposal requires the consent of all persons under whose land the water might migrate it would be practically prohibited).

211. See OKLA. Const. art. II, § 23; Fairfax Oil Corp. v. Bolinger, 97 P.2d 574, 575 (Okla. 1939).

212. 265 P.2d 730 (Okla. 1954). 
Lillard, in contrast, proved the migration of injected fluids diminished their ability to produce oil and gas from existing wells. Those plaintiffs were judged to have a claim for damages. It appears that the rule developing in fluid injection disputes is that landowners are not entitled to exclude third-party injectors from using their subsurface to store injected waste, but injectors are strictly liable for any actual damages caused by the injection. The rule imposes liability where the complaining owner can show an interference with its use rights. This would not be the expected trend if the surface estate's interest in underlying pore space were possessory.

This trespass-based strict liability approach potentially entails two broad problems that could be tempered or avoided by applying common law nuisance. First, the rule does not contain criteria for determining when the injector's conduct is sufficiently important to privilege any resulting invasion. In other words, it is not clear when resulting damages constitute legally actionable injury; or, in the jargon of the early common lawyers, when damnum is injuria. ${ }^{213}$ Nuisance law, in contrast, furnishes rules for determining when resulting damages are wrongful and constitute legal injury. As an example, the Restatement (Second)'s version of nuisance distinguishes mere damages from legal injury by comparing the utility of the offending conduct with the gravity of the resulting harm. Under this version of nuisance, injection activities are privileged, and resulting harm is damnum absque injuria, if the injection is more socially valuable than the harm to the affected subsurface owner is severe. Nuisance is thus capable of distinguishing between harms a subsurface owner must suffer without compensation and those which must be compensated.

Second, strict liability may prohibit capital-intensive socially valuable waste storage activities such as CCS. ${ }^{214}$ The subsurface trespass rule places the costs of an injector's conduct with the injector regardless of whether the injector is best able to bear the costs (i.e., is the least-cost avoider among the parties) or whether the costs may be so great as to render the socially valuable conduct infeasible. Under such an approach a prospective $\mathrm{CO}_{2}$ injector, for example, would not only be potentially liable for all damages caused by its injection, but would also lack a well-

213. Compare BLACK's LAW DiCTIONARY 449, 9th ed. 2009 (defining “damnum" as "a loss; damage suffered"), with id. at 856 (defining "injuria" as a legal wrong). See Halper, supra note 144, at $311 \&$ n.43 ("Bracton said, as an illustration of the difference between damnum and injuria, that one who 'erects a mill on his own land and takes from his neighbor his own suit and that of others; . . . does his neighbor damage but no injuria since he is not prohibited by law or a constitution from having or erecting a mill." (quoting 3 BRACTON, DE LEGIBUS ET CONSUETUDINIBUS ANGLIAE 164 (S. Thorne ed. 1977)).

214. It has been noted that strict liability regimes tend to induce actors to regulate the frequency of activity as well as the level of care in conducting the activity. See STEVEN SHAVELL, AN ECONOMIC ANALYSIS OF ACCIDENT LAW 21-32 (1987) (describing the incentive effects of strict liability regimes). 
defined legal standard for determining liability. It should be further noted that while the rental or use value of pore space for waste storage has been considered de minimis, the advent of commercial CCS (particularly with potentially lucrative tax incentives) may help establish an economic value for this right in certain areas. Consequently, precedent holding that use of another's pore space for fluid disposal is not compensable as actual damages may need to be rethought. As the value increases, courts employing a strict liability standard may find it necessary to compensate nonconsenting owners even if it would render the storage project infeasible.

Additionally, nuisance law provides courts flexibility in tailoring remedies for subsurface invasions. The main remedies available under nuisance encompass compensatory and punitive damages, injunction abating the nuisance, and (rarely) a "compensated injunction" that abates the nuisance but requires the plaintiff to pay the costs of abatement. ${ }^{215}$ Courts also have the discretion to limit or refuse injunctions in private nuisance cases if the defendant is carrying on an activity that is so socially or economically important the injunction would do more harm than good. ${ }^{216} \mathrm{~A}$ great deal of study has been done on the efficiencies available through various nuisance remedies and combinations of remedies. There is a deep literature for litigants and courts to draw from to maximize utility and efficiency in nuisance cases. ${ }^{217}$ Though a discussion of the most efficient remedies for subsurface nuisances exceeds the scope of this Article, it is reasonably clear that the variety of alternatives would improve on the rule of strict liability imposed by trespass.

Nuisance remedies also address Professor Anderson's concern that nonconsenting owners should be compensated for serious damage from invasions. Under the compensation principle, even if the injector's conduct is reasonable, both the unauthorized use of the pore space and any special losses, like damage to producing wells, would be compensable if so severe the plaintiff should not be required to bear them without compensation. This approach would achieve the result desired by the subsurface trespass theory (compensation for damages when fairness requires) without imposing absolute liability on socially beneficial conduct.

It should be noted that a strict-liability approach has (at least) one advantage over utility-balancing: it more clearly specifies property rights,

215. DOBBS ET AL., supra note 120, § 404.

216. $I d$.

217. See id. See generally, e.g., Lewin, supra note 111, at 236-80 (surveying law and economics literature of nuisance). 
which often improves bargaining efficiency between rights holders. ${ }^{218}$ For instance, under Professor Anderson's subsurface trespass theory, ${ }^{219}$ subsurface owners clearly have the right to inject fluid into common reservoirs even if it migrates into a neighbor's portion of the reservoir, but clearly do not have the right to cause any damage to the neighbor as a result. Ideally, given the clarity of these entitlements, a subsurface owner that wanted to inject fluid into a common reservoir could purchase from neighboring owners their right to receive damages and thus avoid disputes before they happen.

The physical reality of subsurface reservoirs, however, means there are many neighbors to bargain with. The presence of multiple players increases transaction costs and the possibility that one will hold out. Moreover, because reservoirs have unique physical characteristics, if bargaining fails or would be prohibitively expensive, the would-be injector may not be able to simply pick up and move to a different one. In the case of resources like interconnected reservoirs, which are depleting resources owned in common among potentially numerous rights holders, the costs of bargaining are high and undermine the simplifying effect of allocating rights in a strict liability regime. ${ }^{220}$ The common law traditionally responded to conditions of high transaction costs with more flexible and discretionary doctrines, like nuisance. ${ }^{221}$

\section{B. Enhanced Recovery Cases}

When initial or "primary" production ${ }^{222}$ of oil and gas from a reservoir ceases, and natural pressures no longer drive reservoir fluids into wellbores for production, it becomes necessary to reenergize the reservoir artificially through "enhanced recovery." 223 Enhanced recovery involves injecting into the depleted reservoir water, chemicals, heat, or $\mathrm{CO}_{2} \cdot{ }^{224}$

218. See Thomas Merrill, Trespass, Nuisance and the Costs of Determining Property Rights, $14 \mathrm{~J}$. LEGAL STUD. 13, 19 (1985) (analyzing property law responses to situations involving higher and lower transaction costs). For the classic articulation of the role of definition of property rights in transaction costs, see generally Ronald Coase, The Problem of Social Cost, 3 J.L. \& ECON. J. (1960).

219. See supra section II.B.1 (discussing Anderson's work). While Anderson's theory clearly specifies entitlements to use another's portion of the reservoir when the use is societally desirable, it does not specify what uses fit this category. This element of the theory may undermine its ability ultimately to define subsurface rights clearly.

220. For a discussion of bargaining and transactions costs in common property, see Carol M. Rose, Energy and Efficiency in the Realignment of Common-Law Water Rights, 19 J. LEGAL STUD. 261, 282-85 (1990).

221. Merrill, supra note 218 , at 19.

222. LOWE, supra note 1 , at 47.

223. Id. at 311-12.

224. Id. at 886-87. Injection of produced water to stimulate production is often termed "secondary recovery" or specifically "waterflooding." Id. 
Enhanced recovery projects usually occur on lands within an oil or gas conservation unit formed by the authority of an administrative agency. Units ideally encompass significant areas of land embracing the full extent of the producing reservoir. Disputes nonetheless arise when injected fluids cross unit boundaries and cause valuable minerals to migrate into the unit from lands outside of the unit.

The legal rule governing such disputes is known as the "negative rule of capture." The negative rule of capture permits unit operators to "inject into a formation substances which may migrate through the structure to the land of others, even if this results in the displacement under such land of more valuable with less valuable substances."225 Courts applying the rule justify this result by the social importance of enhanced recovery for the prevention of waste of hydrocarbon resources and waste from more wells than are necessary to efficiently deplete a reservoir. These cases tend to focus on drainage of hydrocarbons from a nonconsenting owner's property rather than unauthorized use of the owner's pore space. ${ }^{226}$ As with the fluid disposal cases, above, these cases illustrate courts' tendency to call an invasion a trespass while analyzing it like a nuisance.

Railroad Commission of Texas v. Manziel ${ }^{27}$ is one such case. There an unleased landowner sued to set aside a commission order permitting water injection for secondary recovery. The landowner asserted that encroachment of the injected water into his subsurface would constitute a trespass. In holding that the unleased owner may not enjoin any water encroachment, the Manziel Court expended significant space in its opinion extolling the social value of secondary recovery operations. It opined, "[i]t is obvious that secondary recovery programs could not and would not be conducted if any adjoining operator [or landowner] could stop the project on the ground of subsurface trespass." ${ }^{\prime 228}$ Balancing this consideration with the plaintiff's property rights, Manziel ultimately held that the "rules of ownership are of prime importance, but in this consideration the rights of one [the nonconsenting landowner] do not exceed the rights of another [the injector]." ${ }^{229}$ Other courts follow a

225. R.R. Comm'n of Tex. v. Manziel, 361 S.W.2d 560, 568 (Tex. 1962) (quoting HowARD R. Williams \& CHARLES J. MEYERS, OIL \& GAS LAW $\S 204.5$, at 60.2 (1959)). The negative rule of capture is widely followed. See Howard R. Williams \& CHARLES J. MEYERS, Oil \& Gas LAW $\S$ 204.5 (Patrick H. Martin \& Bruce M. Kramer eds., 2018) (collecting cases from numerous jurisdictions applying the rule).

226. Anderson, Subsurface "Trespass," supra note 12, at 272-73.

227. 361 S.W.2d 560 (Tex. 1962).

228. Id. at 568 .

229. Id. at 572. The Texas Supreme Court in Garza appeared to treat Manziel as authority that no trespass whatsoever occurs if water injected pursuant to a Commission-approved secondary recovery unit migrates and drains minerals from lands outside the unit. Coastal Oil \& Gas Corp. v. Garza Energy Tr., 268 S.W.3d 1, 12 (Tex. 2008). It does not appear, however, that Manziel is precedential 
similar approach and generally find that the public value of enhanced recovery justifies any drainage of minerals from nonconsenting landowners. ${ }^{230}$

Courts occasionally award compensatory damages in enhanced recovery cases. In Tidewater Oil Co. v. Jackson, ${ }^{231}$ the Tenth Circuit Court of Appeals permitted plaintiff operators to recover damages to an oil well caused by the defendant's adjoining waterflood. ${ }^{232}$ The plaintiffs alleged the defendant "had injected water at unreasonable and excessive rates in wells located along the boundaries" of a lease adjoining plaintiffs' lease "'and that such injections at such high rates were unreasonable, since the injection wells were deliberately located as close as possible to the property line and immediately opposite and within less than 100 feet of two of the plaintiffs' wells."

The court framed the issue on appeal as "by what standards of tort liability shall the [defendant's] conduct be judged, i.e., trespass, nuisance, negligence, strict liability, or unreasonable use or disregard of another's property." 234 The Tenth Circuit, sitting in diversity jurisdiction, searched Kansas law and found no applicable standard of tort liability for water flooding operations. The most apposite case was Polzin v. National Cooperative Refinery Association ${ }^{235}$ in which the Kansas Supreme Court held that proof of negligence was not essential to establish a statutory cause of action for underground releases of saltwater. ${ }^{236}$ The Jackson Court noted that Oklahoma courts follow a similar approach and that Texas rejects absolute liability in favor of a negligence standard.

Eventually Jackson applied what appears to be a nuisance-like standard, even referencing sections of the Restatement of Torts pertaining to nuisance. ${ }^{237}$ Citing Professors Keeton and Jones the court explained:

[t]hey suggest that orthodox rules and principles applicable to surface invasions should not be appropriately applied to

on that point. Three years after Garza, the Texas Supreme Court, in FPL Farming Ltd. v. Envtl. Processing Sys., L.C., explained that it held in Manziel that "that Railroad Commission authorization of secondary recovery projects are not subject to injunctive relief based on trespass claims." 351 S.W.3d 306, 313 (Tex. 2011) (emphasis added).

230. See, e.g., Crawford v. Hrabe, 44 P.3d 442, Syl. ๆ 5 (Kan. 2002) ("To establish a rule which prevents importation of water for secondary oil and gas recovery, yet requires additional wells to be drilled on the lessor's premises to produce water for the same purpose, would appear to undermine conservation, promote waste, and foster uneconomic actions.").

231. 320 F.2d 157 (10th Cir. 1963), abrogated by Fransen v. Conoco, Inc., 64 F.3d 1481 (10th Cir. 1995).

232. Id. at 165 .

233. Id. at 163 .

234. Id. at 162 .

235. 266 P.2d 293 (Kan. 1954).

236. Tidewater Oil Co., 320 F.2d at 162-63 (citing Polzin, 266 P.2d at 297-98).

237. Id. at 162-63 (citing RESTATEMENT OF TORTS $\S \S 826-32$ \& 822 (AM. LAW INST. 1939)). 
subsurface invasions, arising out of operations affected with a public interest and involving a weighing of the individual interest of the damaged lessee against the social interest involved in the production and conservation of crude oil. ${ }^{238}$

Jackson ultimately concluded that the plaintiffs' claim 'is based upon intentional and unreasonable interference with the claimants' property rights, resulting in actual and substantial damages," and affirmed the trial court's award of lost profits damages for prematurely watering out plaintiffs' wells. ${ }^{239}$

Jackson's analysis is more concerned with the reasonableness of the water flooder's conduct than the type of injury to the plaintiffs' property interest. The latter question is essential in determining liability for subsurface interferences. By applying a nuisance-like standard, however, Jackson implicitly acknowledges that encroaching water infringes an owner's subsurface property rights only if the conduct causing the encroachment unreasonably interferes with the owner's ability to reasonably use the subsurface - which in Jackson meant the owner's ability to produce its existing wells. Relevant considerations in making this determination would include the appropriateness of the conduct to the locality, the actor's ability to avoid the harm, and the utility of the actor's conduct. These are factors in a nuisance analysis under the Second Restatement.

Manziel and Jackson demonstrate the broad trend in enhanced recovery cases to privilege physical invasions of property where a strong public policy reason exists for the conduct causing the invasion. Jackson illustrates that damages may nonetheless be available for injuries caused by excessive or unreasonable injection operations even if conducted pursuant to a regulatory permit. Few clear standards have emerged in these cases and many questions persist: How are courts to weigh the relative utility of a given enhanced recovery operation in comparison with other subsurface activities competing for primacy in a common reservoir? How are they to decide when the operations are conducted in an unreasonable manner? Express application of nuisance doctrine would guide courts in each of these questions and refine the analysis in these cases.

\section{Natural Gas Storage Cases}

Produced natural gas is frequently injected into subsurface strata for temporary storage until winter months when demand for the product is 
high. ${ }^{240}$ Natural gas storage rights are usually acquired by eminent domain under the Natural Gas Act. ${ }^{241}$ Under the act a storage facility must acquire through contract or condemnation the exclusive right to use pore space for gas storage. ${ }^{242}$ Disputes arise in condemnation cases over valuation of the strata and pore space to be used for gas storage. In most cases, however, it is the condemnation of the exclusive right to exploit the substances native to the pore space in the condemned area, and not the value of the strata and pore space itself, that drives the valuation question. ${ }^{243}$

Claims of trespass occur when injected gas migrates from a certificated storage field into the subsurface strata of offsetting owners. ${ }^{244}$ Because natural gas storage rights are typically obtained through use or threat of condemnation, courts tend to treat claims of trespass arising from the migration of injected natural gas from a storage facility as actions in inverse condemnation. ${ }^{245}$ Moreover, because gas has a market value, most of the natural gas storage cases focus on ownership of the stored gas rather than the invasion that occurs when injected gas strays from the confines of the storage facility. ${ }^{246}$

Courts generally do not award compensation for unauthorized use of pore space for gas storage absent a showing of interference with use of the property. Although widely criticized, some courts follow Hammonds v. Central Kentucky Natural Gas Co. ${ }^{247}$ which held that escaped natural gas from a storage facility did not trespass on the plaintiff's subsurface because the gas storage company had abandoned the gas when it escaped. ${ }^{248}$ Other jurisdictions have rejected Hammonds's reasoning in

240. ANR Pipeline Co. v. 60 Acres of Land, 418 F. Supp. 2d 933, 937 (W.D. Mich. 2006).

241. 15 U.S.C. $\S \S 717-717 \mathrm{z}$ (Supp. 2012). The act permits private natural gas companies to obtain certificates of public convenience empowering them to condemn private property for constructing underground natural gas storage facilities. $I d$.

242. Gresham \& Anderson, supra note 31, at 725.

243. Id. at 724 ("[D]isputes may arise over the valuation of the storage space, but it is well settled that compensation must be paid when the exclusive right to protect the storage strata by condemning all other exploitation of the strata and its contents is acquired by the natural gas company.").

244. Id. at $724-25$.

245. Id. at 730 .

246. Id.

247. 75 S.W.2d 204 (Ky. 1934). Hammonds analogized stored natural gas to captured wild animals to hold that "if in fact the gas turned loose in the earth wandered into the plaintiff's land, the defendant is not liable to her for the value of the use of her property, for the company ceased to be the exclusive owner of the whole of the gas - it again became mineral faere naturae" and again subject to capture. Id. at 206 .

248. For example, the Hammonds doctrine applies in Kansas when a person uses the subsurface of another to store natural gas without authority or compensation and no natural gas public utility is involved and no certificate authorizing a natural gas storage facility has been issued. Anderson v. Beech Aircraft Corp. 699 P.2d 1023, 1032 (Kan. 1985). Notably, the Oklahoma Supreme Court applied Hammonds-like logic in West Edmond Salt Water Disposal Ass' $n$ v. Rosecrans, a case involving disposal of produced water, where it held there was no liability for migration of injected 
favor of finding that escaped storage gas remains the property of the storage company. But few cases in non-Hammond jurisdictions have squarely addressed whether the escape of storage gas into a nonconsenting owner's pore space constitutes a trespass or a taking. ${ }^{249}$

Rejecting Hammonds a Michigan federal court stated in ANR Pipeline Co. v. 60 Acres of Land $d^{250}$ that "if injected gas moves across boundaries there may be a trespass," and if the intrusion was caused by a gas storage company with condemnation authority the invasion may furnish a basis for a claim of inverse condemnation. ${ }^{251}$ The court, however, distinguished intrusions of native "cushion" gas, which is displaced from the storage facility by injection of storage gas, because it is not foreign to the reservoir. ${ }^{252}$ The court held that no compensation is due for use of pore space to store cushion gas unless the claimant can show some harm, such as interference with use of the property. ${ }^{253}$

ANR Pipeline did not analyze whether use of another's pore space without permission to store natural gas would constitute an actionable trespass. The case nonetheless illustrates courts' reluctance to consider the underground movement of fluids to be physical intrusions and their tendency to award compensation only where the plaintiff proves impairment of use. The only compensable injury a subsurface owner suffers by the condemnation of reservoir space for gas storage or intrusion by injected or displaced gas is an interference with use of the property. There is no compensable injury for loss of possession.

This point was made explicitly by the Sixth Circuit in Baatz v. Columbia Gas Transmission, LLC. ${ }^{254}$ Following Chance v. BP Chemicals, Inc. ${ }^{255}$ Baatz denied landowners' claims of trespass and unjust enrichment against Columbia for storing natural gas under their land without permission or a condemnation order. ${ }^{256}$ Absent a showing of actual or foreseeable use of the subsurface, Baatz held, the landowners

\footnotetext{
saltwater, in part because "[u]nder all the authorities we have been able to find upon the subject, the assumption that the salt water remained the property of defendants after it permeated or penetrated into the ... formation underlying the land of plaintiffs is incorrect." 226 P.2d 965, 970 (Okla. 1950).

249. See generally Gresham \& Anderson, supra note 31, at 723-33 (surveying natural gas storage cases touching on trespass issues).

250. 418 F. Supp. 2d 933 (W.D. Mich. 2006).

251. Id. at 940 .

252. Id.

253. Id. at 941 .

254. 929 F.3d 767 (6th Cir. 2019).

255. See supra section IV.A.

256. Baatz, 929 F.3d at 773, 777.
} 
could not establish that the gas storage violated a possessory interest or entitled them to restitution. ${ }^{257}$

\section{Tunneling and Directional Drilling Cases}

This section discusses cases involving various forms of tunneling under nonconsenting owners' land. For present purposes "tunneling" includes drilling oil or gas wells. The tunneling cases discussed below indicate courts are unwilling to compensate a landowner for the mere presence of an unauthorized tunnel or wellbore. Claimants must show interference with use or enjoyment of the surface or minerals in the property to justify relief. Since courts in these cases already treat them as nontrespassory in nature, applying a nuisance analysis would rationalize the results and furnish a reasoned approach to determining when a plaintiff's lost use value justifies compensation.

\section{Tunnels Not for Oil and Gas Purposes}

Early cases reached mixed results on whether tunneling beneath private property without permission violates the owner's subsurface rights. While some courts appeared to consider subsurface property as fully possessory as surface property, others, like New York courts, did not. In Boehringer v. Montalto ${ }^{258}$ the New York Supreme Court explained that "the title of an owner of the soil will not be extended to a depth below ground beyond which the owner may not reasonably make use thereof," and concluded that a proposed 150 -foot deep sewer was beyond this point. ${ }^{259}$ Likewise, in In re Tunnel Street in New York, the court held,

[t]he effect of the improvement contemplated in this proceeding is to take a tunnel through appellants' property 150 feet below the surface. It will not restrict the superficial area of the property[,] or in any way interfere with its improvement or development. Save for the bore taken for the tunnel[,] the appellants will own their property as absolutely as they now own it.... The appellants' claim for damage ... impresses us as unsubstantial and fanciful, with no sound basis to rest upon. ${ }^{260}$

257. Id. at 777. For a case affirming an award of damages for trespass and unjust enrichment on similar facts, see Beck v. N. Nat. Gas Co., 170 F.3d 1018 (10th Cir. 1999) (applying Kansas law).

258. 254 N.Y.S. 276 (N.Y. Sup. Ct. 1931).

259. Id. at 278; see also In re Gillespie, 17 N.Y.S.2d 560, 563-64 (N.Y. Sup. Ct. 1940) (regarding a tunnel buried 470 to 500 feet deep).

260. 144 N.Y.S. 1002, 1002 (N.Y. App. Div. 1913), aff'd, 106 N.E. 1043 (N.Y. 1914). 
Compare the New York tunneling cases with Smith v. City of Atlanta, ${ }^{261}$ where the Georgia Supreme Court applied the ad coelum doctrine to the subsurface. ${ }^{262}$ Smith found the city's tunneling under the plaintiff's lot did not affect the lot's market value but nonetheless held it constituted a taking of the plaintiff's property. ${ }^{263}$ In its brief reasoning Smith explains that ad coelum applies "upwards as well as downwards" such that "[a]11 the earth removed belonged to the plaintiffs, and unquestionably by the location of the sewer they were deprived of the possession of space it occupied, and could no longer use that space for any other purpose."264 The plaintiff alleged loss of income from selling sand from the area where the tunnel was dug. The court criticized the plaintiffs' allegations as "imperfectly drawn" but held that "a verdict in favor of the plaintiffs for some amount - certainly for at least nominal damages - was demanded by the evidence." ${ }^{265}$ The court ultimately reversed the lower court's denial of a new trial on the proper amount of compensation and remanded the case for determination of the lost use value.

Similarly the city in City of Chicago v. Troy Laundry Machine Company ${ }^{266}$ was held liable for trespass for digging a tunnel fifty-five feet below the surface of property without the owner's knowledge. ${ }^{267}$ When the owner constructed a building on the property six years later, water flowing through the city's tunnel eroded the soil and caused the building to sink. The court stated that both the tunnel's original construction and the water flowing through the tunnel constituted trespasses but noted the building of the tunnel was "a mere historic incident in the case." 268 The court ultimately upheld the plaintiff's verdict for damages caused by the erosion of the surface.

Early commentators grappled with the contrariety in these and other early subsurface use cases. Certain decisions, including Smith and Troy Laundry Machine, prompted one scholar to remark in 1927 that the subsurface appears to be "something which can be owned, and is owned, subject, of course, to the limitations imposed by our modes of life ...."269 This characterization did not account for the New York cases finding no compensable property interest in the subsurface. Moreover, neither Smith

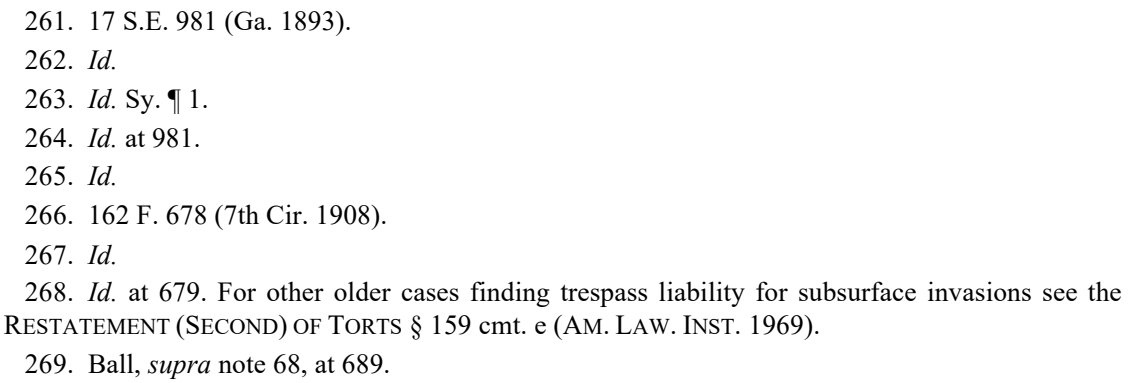


nor Troy Laundry Machine holds that subsurface tunneling interferes with the surface owner's possessory right in the subsurface. Although Smith appears to hold that the plaintiff was entitled at least to nominal damages for the sewer tunnel under his property, the case was ultimately remanded for a new trial on the value of the plaintiff's surface uses impaired by the tunneling. And although Troy Laundry Machine states the mere digging of the tunnel was a trespass, this statement was not necessary to the disposition of the case, which was decided based on the plaintiff's lost use value in the surface and building as a result of the tunnel. ${ }^{270}$

These cases show that early courts agreed surface ownership includes a negative right to be free from subsurface interferences that inhibit use of the surface. ${ }^{271}$ Subsurface tunneling is compensable when it violates the surface owner's negative right (as in Smith and Troy Laundry Machine) and is not when it does not (as in the New York cases). Synthesizing the cases this way leads to a conclusion, similar to Dean Wigmore's, that the subsurface is akin to an incorporeal appurtenance of the surface.

\section{Slant-Hole and Directional Wellbores}

Drillers sometimes deviate or slant boreholes to produce minerals from a portion of reservoir not directly beneath the surface location of the well. Unscrupulous drillers do so with the intent of bottoming the producing portion of a well under neighboring property to surreptitiously produce oil or gas from their neighbor's land. ${ }^{272}$ Affected subsurface owners typically sue slant-hole drillers for two causes of action: trespass and conversion of the oil or gas. As California Court of Appeals in Alphonzo E. Bell Corp. v. Bell View Oil Syndicate ${ }^{273}$ explained in one such slant-hole trespass and conversion case, "[w]e do not need to discuss the injury to the real estate, as these actions are not based upon damages suffered to the real estate but are based upon the wrongful conversion of oil, gas, and other hydrocarbons from beneath the property."274

270. City of Chi. v. Troy Laundry Mach. Co., 162 F. 678 (7th Cir. 1908).

271. Even the New York holdings leave room for a takings claim for underground tunneling if it would interfere with the development of the surface. See In re Tunnel St. in N.Y., 144 N.Y.S. 1002, 1002 (N.Y. App. Div. 1913), aff'd, 106 N.E. 1043 (N.Y. 1914).

272. See generally Mortimer Kline, Subsurface Trespassing, 5 J. MARSHALL L.Q. 30 (1939) (describing the problem as a matter of trespass and conversion); Note, Suing a Slant-Driller for Subsurface Trespass or Drainage, 15 STAN. L. REV. 665, 680 (1963) (describing the issue and noting that slant-hole invasions appear to be the earliest subsurface trespass cases arising in the oil and gas industry).

273. 76 P.2d 167 (Cal. Ct. App. 1938).

274. Id. at 175 . 
Many slant-hole cases also involve requests for injunction. In Union Oil of California v. Domengeaux, ${ }^{275}$ Union Oil sued to enjoin Domengeaux from operating a deviated well located on the surface of Domengeaux's land but that had been completed under Union Oil's lease ${ }^{276}$ Before Domengeaux commenced drilling, Union Oil warned him not to "cause or permit said well to cross or be within the boundary lines of" Union Oil's lease. ${ }^{277}$ Domengeaux ignored the warning and drilled the deviated well.

Union Oil sued for injunctive relief and damages but abandoned its damages claim at trial because of the difficulty in proving where the produced oil originated. ${ }^{278}$ The appellate court upheld an order enjoining Domengeaux to plug back the well to a bottom-hole location within Domengeaux's lease boundaries even though Union Oil showed no actual damages. "Before leaving the point," however, the court stated,

we do not wish to be understood as holding that every subsurface trespass in the drilling of an oil well would warrant injunctive relief. We can conceive of an oil well deviating slightly from the perpendicular, trespassing to a small extent upon the land of an adjoining owner and returning to oil-producing strata within the property of the owner of the well. In such case, the damage, if any, to the adjoining owners might be said to be wholly inconsequential and equitable relief might be properly withheld. ${ }^{279}$

As in the non-oil and gas tunneling cases, liability in slant-hole well cases depends on the loss of the property's available economic use - production of valuable minerals - and not on the physical invasion of the plaintiff's subsurface by defendant's wellbore. Subsurface intrusions by deviated wellbores must not be trespassory invasions because they are not actionable unless they also deprive the subsurface owner of the economic value of underlying mineral reserves.

The nontrespassory nature of nonproducing wellbores is further illustrated by the recent Texas Supreme Court case of Lightning Oil Co. v. Anadarko E\&P OnShore, $L L C .{ }^{280}$ Lightning Oil involved a dispute over use of a common reservoir for oil and gas production between Lightning and Anadarko. Lightning owned an oil and gas lease covering the Briscoe

275. 86 P.2d 127 (Cal. Ct. App. 1939).

276. Id. at 128 .

277. Id. at 129.

278. Id. at 130 .

279. Id

280. 520 S.W.3d 39, 49 (Tex. 2017). 
Ranch. ${ }^{281}$ Anadarko owned an oil and gas lease on adjoining property that strictly limited use of the surface for drilling. ${ }^{282}$ Anadarko obtained the permission of the surface owner of the Briscoe Ranch to drill horizontal wellbores from a location on the Ranch to produce from its adjoining leasehold. ${ }^{283}$ Anadarko did not intend to produce along any portion of the wellbores under the Ranch. ${ }^{284}$ Lightning nevertheless objected to Anadarko's drilling anywhere under the Ranch and sued for trespass, tortious interference, and injunction. ${ }^{285}$

The Texas Supreme Court declared the surface owner "owns all nonmineral 'molecules' of the land, i.e., the mass that undergirds the surface," 286 as well as the "reservoir [storage] space" 287 under the surface. It further stated that an oil and gas lessee owns the right to develop associated with the severed mineral estate, which it described as "the exclusive right to appropriate [the minerals], ${ }^{, 288}$ but does not own the "right to possess the specific place or space where the minerals are located."289 From these principles the court reasoned that "an unauthorized interference with the place where the minerals are located constitutes a trespass as to the mineral estate only if the interference infringes on the mineral lessee's ability to exercise its rights." ${ }^{\text {290 }}$ The court ultimately held that Lightning failed to offer sufficient proof that Anadarko's proposed well sites, drilling activities, and underground well structures would interfere with surface and subsurface spaces necessary for Lightning to develop the minerals. ${ }^{291}$ The court further held that any minerals lost as a result of Anadarko's drilling through the subsurface were outweighed by the interests of the public in maximizing recovery of oil and gas. ${ }^{292}$

Contrast Lightning Oil with Chevron Oil Company v. Howell ${ }^{293}$ where Chevron appealed from a temporary injunction restraining it from drilling

281. Id. at 43 .

282. $I d$.

283. $I$.

284. Id.

285. Id.

286. Id. at 46 (first quoting Lightning Oil Co. v. Anadarko E\&P Onshore, LLC, 480 S.W.3d 628, 633-35 (Tex. Ct. App. 2015), and then quoting Dunn-McCampbell Royalty Interest, Inc. v. Nat'l Park Serv., 630 F.3d 431, 441 (5th Cir. 2011)).

287. Id. (first quoting Lightning Oil Co., 480 S.W.3d at 633-35, then quoting West, 480 S.W.3d at 815 .

288. Id. at 47-48 (quoting Stephens Cnty. v. Mid-Kan. Oil \& Gas Co., 254 S.W. 290, 293-94 (Tex. 1923)).

289. Id. at 49.

290. Id. (emphasis added).

291. Id.

292. Id. at 51.

293. 407 S.W.2d 525 (Tex. Ct. App. 1966). 
a directional well through a subsurface tract to access minerals it leased under Lake Texoma. ${ }^{294}$ Chevron argued that its directional wellbore did not interfere with the rights of the mineral lessee in the subsurface tract and should not be enjoined. The court disagreed based on testimony of Chevron's superintendent that "any time you drill into something there is bound to be some damage." 295

It is difficult to reconcile Lightning Oil with the slant-hole well cases and Howell under a trespass analysis. Whereas in the slant-hole well cases the loss of minerals resulting from an intruding wellbore is compensable, the court in Lightning Oil declined to award Lightning damages for loss of minerals. And whereas in Howell the potential for damage to the mineral lessee's ability to exploit its interest was sufficient to enjoin Chevron's plans for a horizontal wellbore, in Lightning Oil Anadarko was permitted to drill its horizontal wellbores even though Lightning showed it would lose some use of its mineral interest as a result.

These cases are reconcilable under a utility-balancing nuisance analysis. Under nuisance, the destruction or drainage of minerals by an intruding wellbore would be compensable if the gravity of the harm to the nonconsenting owner (likely measurable by lost production) outweighs the utility of drilling the wellbore to the defendant driller and the public. Within this framework a slant-hole driller like Domengeaux would have to show a compelling societal need to produce the well bottomed under Union Oil's lease to justify the serious loss of minerals Union Oil is likely to suffer as a result. Alternatively, under nuisance's compensation principle, Union Oil's loss of minerals may be so severe that no balancing is necessary. It is clear from the court's opinion in Domengeaux, however, that there was no justification for Domengeaux's actions that would counterbalance Union Oil's inevitable losses. Injunction was therefore appropriate.

In Lightning Oil, on the other hand, the utility of Anadarko's horizontal drilling operation was high. It was necessary to produce minerals that Anadarko was entitled to under its lease but otherwise could not access because of the lease's surface use restrictions. The harm to Lightning's ability to exploit its mineral interest was not significant in comparison since it had no plans to develop the portion of the property where Anadarko would drill and the amount of recoverable oil or gas that would be lost by the wellbore would be quite small. By permitting Anadarko to drill through the necessary portion of Lightning's mineral estate the Lightning Oil Court coordinated use of the subsurface of the Briscoe Ranch to maximize efficiency of its use. 
Viewed as nuisance cases, Lightning Oil is also distinguishable from Howell based on the relative harm-to-utility ratio presented in each case. In Howell, Chevron's superintendent admitted the directional wellbore would damage the nonconsenting mineral owner's reservoir. But unlike Anadarko in Lightning Oil, Chevron apparently failed to raise any argument to justify the damage. Chevron urged instead that its directional wellbore would not interfere at all with the nonconsenting owner's mineral interest. Under a utilitarian nuisance analysis these cases are distinguishable based on the strength of the evidence of the utility of the interfering conduct.

\section{E. Hydraulic Fracturing Cases}

Hydraulically fracturing (fracking) a well creates artificial fractures in reservoir rock to increase permeability and stimulate its productive capacity. Fracking involves pumping fluid and proppants into the wellbore under immense pressure. The resulting fractures, called "frac fissures," can radiate hundreds of feet laterally from the wellbore, even travelling beyond property lines to fracture rock and deposit fluid and proppants in the subsurface of another. ${ }^{296}$ The high pressures created by frac jobs can also flow through frac fissures and interfere with existing wellbores on other property. ${ }^{297}$ This problem, called "frac hits," most commonly occurs where a newly drilled horizontal well is hydraulically fractured in a field where vertical wells already produce. ${ }^{298}$ Some state regulatory agencies have promulgated planning requirements for newly fractured wells as a means of avoiding frac hits. ${ }^{299}$ For the most part,

296. Frac fissures are typically thousands of feet in length but their effective length is frequently less than one hundred feet long. The "effective length" of a frac fissure is the portion that actually drains hydrocarbons from the reservoir into the wellbore. The "propped length" of a frac fissure is the portion that is held open by the proppants pumped in the fracturing treatment. The propped length is usually much greater than the effective length. Greater still is the "hydraulic length" which is the farthest extent of the fracturing fluids not including proppants. Coastal Oil \& Gas Corp. v. Garza Energy Tr., 268 S.W.3d 1, 7 (Tex. 2008).

297. Oil and Gas; Hydraulic Fracturing on Federal \& Indian Lands, 80 Fed. Reg. 16,128, 16,18116,182 (Mar. 26, 2015) (defining this phenomenon as, the "unplanned interconnectivity of wells during a hydraulic fracturing operation though the underground formations between the well undergoing a fracturing operation and an existing well").

298. See Pierce, supra note 43, at 264; see, e.g., Max Oil Co. v. Range Prod. Co., 681 F. App'x 710, 711-12 (10th Cir. 2017) (dismissing as untimely claims of negligence, trespass, nuisance, and conversion brought by a vertical well operator against a horizontal well operator based on damage alleged to have occurred to the plaintiff's vertical well as a result of the defendant's fracturing of its horizontal well). Nonetheless, frac hits can occur wherever two wells are in close proximity and opened to the same reservoir. Christiansen \& Pierce, supra note 5, at 12-2.

299. E.g., Colo. Oil \& GAS CONSERVATion COMM'N, INTERIM StATEWIDE Horizontal OfFSET POLICY, at 1 (Feb. 10, 2014), https://cogec.state.co.us/documents/reg/Policies/ InterimStatewideHorizontalOffsetPolicy.pdf [https://perma.cc/5QP2-6N4J]. 
however, the risk of frac hits is dealt with by cooperative bargaining or litigation among operators within a common reservoir. ${ }^{300}$

Fracturing operations are thus ripe for litigation in two relevant categories of circumstances: when frac fissures, fluids, and proppants cross property lines and drain minerals from another's subsurface, and when frac pressures communicate across property lines and interfere with production from existing wells. As examined below, courts' classification of such invasions as trespassory or nontrespassory varies widely. Such disputes may be resolved efficiently and equitably by a nuisance analysis.

\section{Fracking Resulting in Drainage}

When frac fissures, fluids, and proppants extend past the boundaries of the owner's land and into adjoining land the issue arises whether any hydrocarbons drained from the adjoining land become the property of the fracking owner under the rule of capture. In considering this question courts have applied a trespass analysis based on the ad coelum doctrine's definition of surface and subsurface ownership as modified by the rule of capture. Under the rule of capture, any hydrocarbons drained from adjoining land by a well located within the ad coelum-defined surface and subsurface boundaries of the well owner's land and produced in compliance with conservation laws are the well owner's legitimate property. ${ }^{301}$ If, in contrast, a well is drilled and bottomed in the subsurface of another's land, "the driller has committed a trespass," and any hydrocarbons produced by the well's owner are illegitimate and not privileged under the rule of capture. ${ }^{302}$ Consequently hydraulic fracturing precedent focuses on whether cross-boundary frac fissures and proppants constitute a trespass. ${ }^{303}$

300. See Christiansen \& Pierce, supra note 5, at 12-10-12-11 (describing the informal and voluntary process by which operators intending to complete fracking operations consult operators of proximate vertical wells to resolve potential issues arising from frac hits).

301. See 1 KUNTZ, supra note 54, at 325-26 ("Such [capture] right must, however, be exercised by operations within the vertical boundaries of the owner's tract of land. If a well is drilled in such a manner that it is bottomed under the land of another, the driller has committed a trespass."); accord Alphonzo E. Bell Corp. v. Bell View Oil Syndicate, 76 P.2d 167, 175 (Cal. Ct. App. 1938); Wronski v. Sun Oil Co., 279 N.W.2d 564, 571 (Mich. Ct. App. 1979) (holding that "any violation of a proration order constitutes conversion of oil from the pool, and subjects the violator to liability to all the owners of interests in the pool for conversion of the illegally-obtained oil" (internal citations omitted)).

302. 1 KUNTZ, supra note 54, at 325-26.

303. Despite arising decades ago this question has only recently been directly litigated. A trio of older Texas cases, which did not address the question squarely, appeared to presume that fracturing under the property of another would constitute a trespass and thus that any drainage of hydrocarbons from the fissures would not be protected by the rule of capture. See Geo Viking, Inc. v. Tex-Lee Operating Co., 817 S.W.2d 357 (Tex. Ct. App. 1991); Delhi-Taylor Oil Corp. v. Holmes, 344 S.W.2d 421 (Tex. 1961); Gregg v. Delhi-Taylor Oil Corp., 344 S.W.2d 411 (Tex. 1961). 
In 2008, the Texas Supreme Court held in Coastal Oil \& Gas Corp. v. Garza Energy Trust $^{304}$ that a subsurface invasion by frac fissures was not an actionable trespass and permitted the fracking party to retain hydrocarbons drained from the plaintiffs' adjoining lands. ${ }^{305}$ Coastal owned the oil and gas lease on Share 13 and also owned the fee mineral interest in the adjoining Share 12. The Salinas parties were the lessors under Coastal's lease on Share 13 and thus owned the possibility of reverter in the minerals. Coastal fracked a well on Share 12 to produce natural gas from the Vicksburg T formation underlying both Share 12 and Share 13. The parties agreed both the hydraulic and propped lengths of the fractures traveled under Share 13; they did not agree whether the effective length did. ${ }^{306}$ Upset the fractures might drain natural gas from Share 13 and deprive them of royalties on the drained gas, the Salinas parties sued for trespass. The court denied the Salinas parties relief finding that Coastal had a right to drain hydrocarbons from the Salinas parties' tract under the rule of capture. ${ }^{307}$

Because the Salinas parties had granted Coastal an oil and gas lease on Share 13, under Texas law the Salinas parties owned only a future interest in the mineral estate - a possibility of reverter. Since future interests are nonpossessory the Salinas parties could not state a claim for trespass quare clausum fregit and could proceed only under a claim for trespass on the case. Unlike trespass quare clausum fregit trespass on the case requires a showing of actual damages. ${ }^{308}$ The only damages claimed by the Salinas parties consisted of drainage of natural gas from Share 13 to Coastal's well on Share 12. The Garza Court ultimately held that any drainage damages would be precluded by the rule of capture. Since the Salinas parties needed to show damages for their trespass cause of action, they could not articulate an actionable trespass.

Writing for the dissent Justice Johnson criticized the majority for not determining whether the extension of frac fissures into a nonconsenting owner's property constitutes a trespass in the first instance, noting that the rule of capture would not apply to permit an operator to drain a neighbor's hydrocarbons by trespassory conduct. ${ }^{309}$ The dissent then analogized frac fissures to deviated wellbores that are intentionally bottomed in another's land and reasoned that, like deviated wells, frac fissures would constitute a trespass under Texas precedent.

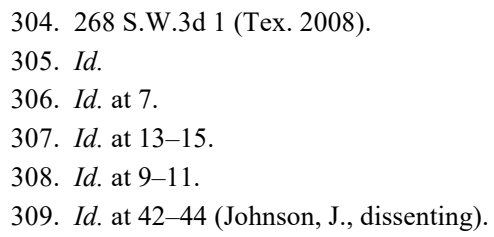


The Garza majority cited four justifications for finding no "actionable trespass." Each justification turns on the public policy rationale that hydraulic fracturing should be promoted because it prevents waste by enabling production of tight reservoirs, like the Vicksburg T, that would otherwise be unproductive. ${ }^{310}$ In concurrence Justice Willett wrote that he would extend these policy justifications to hold that trespasses-by-frac are no trespass at all based on the social value of increasing production of oil and gas through hydraulic fracturing. ${ }^{311}$ Per Willett, "Balancing the respective interests [of the industry and society as a whole and of the plaintiffs' particular interests,] ... this type of subsurface encroachment ... simply isn't wrongful and thus isn't a trespass at all, not just a nonactionable trespass. ${ } 312$

The Garza majority's balancing of public policy reasons for and against establishing liability for the invasion is akin to nuisance law's balance of utilities test, not to the property rule of trespass. Despite framing the issue as whether the encroachment of frac fissures is a trespass, Garza approached the case much as a court would in determining a nuisance case. ${ }^{313}$ Yet, because Garza assumed any invasion would be trespassory, it lacked the articulable standards of nuisance for striking an efficient and equitable balance between the parties' conflicting interests in use of the subsurface. Garza instead engaged in an ad hoc public policy analysis.

Courts outside of Texas have not followed Garza. In Stone v. Chesapeake Appalachia, $L L C^{314}$ the Northern District of West Virginia, on facts similar to those in Garza, reaffirmed the ad coelum doctrine and the traditional standard for trespass liability. ${ }^{315}$ The Stone Court held that frac fissures travelling under a nonconsenting owner's land constitute an actionable trespass and therefore that drainage through cross-boundary frac fissures is not privileged under the rule of capture. ${ }^{316}$ In so holding, Stone rejected the Garza majority's analysis, adopting instead Justice Johnson's reasoning, and added that Garza placed "the desires of the

\footnotetext{
310. Id. at $16-17$.

311. Id. at 29.

312. Id. at 30 . INST. 1969)).

314. No. 5:12-CV-102, 2013 WL 2097397 (N.D. W. Va. Apr. 10, 2013).

315. Id.

316. Id. at *7-8.
}

313. See, e.g., Cyr v. Town of Brookfield, 216 A.2d 198, 200-01 (Conn. 1965) (reversing the trial court's dismissal of plaintiff's claim of nuisance against a municipality for its operation of a sewer system on the basis that factfinding is necessary to determine whether under the balance of utilities test the municipality's invasion of the plaintiff's use and enjoyment of the land outweighed the utility of the municipality's conduct (citing Restatement (SECOND) OF TORTS $\S 822$ (AM. LAW 
industry" over "the property rights of small landowners" who would be drained by off-lease fracturing even if they did not consent to drilling or production on their land. ${ }^{317}$

An intermediate-level appellate court in Pennsylvania also found that cross-boundary frac fissures constitute a trespassory invasion of a nonconsenting owner's property in Briggs v. Southwestern Energy Production Co ${ }^{318}$ Like Stone, Briggs held that the rule of capture does not preclude an action for drainage damages from unauthorized frac fissures. Briggs's analysis focused on the unique characteristics of the tight shale gas reservoir at issue. Unlike in conventional oil and gas reservoirs, the court explained, gas trapped in tight shales is nonmigratory in nature and does not escape to adjoining land absent application of external, nonnatural forces like fracking. By this reasoning Briggs concluded the rule of capture does not apply to capture of hydrocarbons through crossboundary frac fissures in the same way it applies to capture through conventional means of production. ${ }^{319}$

The threshold question in trespass-by-frac cases is whether the entry of a frac fissure into the subsurface of another violates a statute or regulation or infringes the other's property rights. If so, the rule of capture should not apply and any drainage occasioned by the cross-boundary frac fissures should not be privileged. ${ }^{320}$ Garza, Stone, and Briggs illustrate the difficulty in making the threshold determination under a one-size-fits-all rule that every cross-boundary frac fissure is or is not a trespass. Under Garza a cross-boundary frac fissure may never be an actionable tort, which may disadvantage small-tract owners in favor of broader public interests even where it may not serve equity or public policy to do so. In contrast jurisdictions following Briggs or Stone may reach socially disadvantageous results by subordinating the importance of fracking and

317. Id. at *6-7.

318. Briggs v. Sw. Energy Prod. Co., 184 A.3d 153, 163-64 (Pa. Super. Ct. 2018) (holding that hydraulic fracturing does not alter the operation of the rule of capture, and that liability for drainage caused by hydraulic fracturing, if at all, would be predicated on a showing that hydraulic fractures physically invade the plaintiff's subsurface), vacated and remanded by No. 63-MAP-2018, 2020 WL 355911 (Pa. Jan. 22, 2020).

319. Id. at 162-63. The Pennsylvania Supreme Court has granted review on the following issue:

Does the rule of capture apply to oil and gas produced from wells that were completed using hydraulic fracturing and preclude trespass liability for allegedly draining oil or gas from under nearby property, where the well is drilled solely on and beneath the driller's own property and the hydraulic fracturing fluids are injected solely on or beneath the driller's own property? Briggs v. Sw. Energy Prod. Co., 197 A.3d 1168 (Table) (2018).

320. See People's Gas Co. v. Tyner, 31 N.E. 59, 59-61 (Ind. 1892) (holding that the rule of capture does not privilege conduct that would otherwise constitute a common law tort such as nuisance); Wronski v. Sun Oil Co., 279 N.W.2d 564 (Mich. Ct. App. 1979) (holding that drainage in violation of conservation statutes is not privileged under the rule of capture and constitutes conversion). 
efficient hydrocarbon production in favor of the rights of small-tract owners in every case.

Liability for frac invasions is better determined on a flexible, case-bycase basis under nuisance. The outcomes in frac invasion cases will vary under a utilitarian nuisance standard depending on the relative utility of the frac operations at issue and the gravity of the harm to, and utility of, the plaintiff's subsurface activities - all in the context of the character of the local reservoir. ${ }^{321}$ Courts already consider the relative importance of the parties' competing subsurface activities to determine liability in fracking cases. However, the holdings in Garza, Briggs, and Stone fail to acknowledge that a balancing test is inappropriate for determining breach of a party's right of possession. Interest- or utility-balancing is only appropriate, if ever, instead for resolving clashes of discordant use of common property.

The hydraulic fracturing cases are doctrinally inconsistent because they misidentify the primary property right at stake, which is the right of use and not possession. Because the courts have couched the question in terms of whether a frac invasion is a trespass (as opposed to nuisance) their holdings do not easily accommodate differing results in cases involving unique facts. On the contrary if a cross-boundary frac fissure breaches the affected owner's possessory interest in one case, it should be a breach in every case. Many of the factual variables that make frac invasion cases difficult are easier to reconcile under a nuisance framework. Treating frac invasions as nuisances would permit courts greater flexibility to consider factors like reservoir characteristics and the commonness of hydraulic fracturing within the reservoir in determining the appropriateness of the operations to the character of the area.

Nuisance principles also provide a framework for evaluating the potential harmfulness of a frac invasion to a plaintiff's interest. For instance, if the effective length of a frac fissure crosses into a nonconsenting owner's land, it would be likelier to cause severe harm through drainage than if only the propped length (which does not cause drainage) crosses the property line. Under a true trespass analysis both fissures would be equally invasive and actionable. Under a nuisance analysis, in contrast, the gravity of the invasion would depend on the likelihood of the fracture to cause drainage. Whether any resulting drainage is privileged under the rule of capture would depend on whether

321. When the generic type of dispute in these cases is properly framed as being between competing uses of property, the fact that courts in different places at different times resolve similar cases differently becomes reconcilable doctrinally. See Jeremiah Smith, Reasonable Use of One's Own Property as a Justification for Damage to a Neighbor, 17 COLUM. L. REV. 383, 402 \& nn.88-90 (1917) (noting in his discussion of the then-present state of nuisance law that "[ $t$ ]he question of superiority between two modes of user may be, and has been, decided differently in the same state at different dates"). 
the severity of the harm to the plaintiff outweighs the utility of the defendant's actions. If so the rule of capture would not apply, and the drainage would be compensable.

By properly identifying the property right at stake - the right of use and enjoyment - and applying the appropriate remedial legal regimenuisance - it is possible to achieve doctrinal consistency across and within jurisdictions. Even if the results in these cases would not change if analyzed as a nuisance, properly framing the nature of the invasion and applying the corresponding tort regime would harmonize the disparate results and lend coherence to the area of law.

\section{Frac Hits}

There does not yet appear to be an appellate case addressing the merits of a frac-hit dispute. ${ }^{322}$ Mark Christiansen and Professor David Pierce have sketched the paradigm frac-hit dispute as follows:

[A]ssume a reservoir owner desires to drill a horizontal well in a reservoir containing an existing vertical well. The horizontal well developer is concerned about avoiding or minimizing any interwellbore communication with an offsetting vertical well. Assume the remedy is to shut in the vertical well while the horizontal well is undergoing hydraulic fracturing. Suppose the vertical well owner (1) refuses to shut in, (2) demands compensation for lost revenue during the shut-in period, or (3) asserts damage to the well or the reservoir. How will these issues be resolved? ${ }^{323}$

Frac hits pose basic resource allocation questions: where two operators desire to produce oil or gas from a common reservoir by conflicting means, one by a preexisting vertical well and the other by a newly fracked horizontal well, which means of production should prevail? Which operator's property rights entitle it to produce by its preferred means? ${ }^{324}$

Trespass would be a poor analytical tool for resolving these issues because, as illustrated by Garza, Briggs, and Stone, it imposes a strict, absolute-liability-or-nothing standard despite the unique circumstances of a given case. Moreover, a trespass analysis would focus on the physical or nonphysical nature of the intrusion, which sheds little light in a competition between nonpossessory use rights. Nor would a trespass

322. See Christiansen \& Pierce, supra note 5, at 12-11 ("A number of low-profile lawsuits have been filed by vertical well operators against operators of new horizontal wells alleging that the plaintiff's vertical well was damaged as a result of a frac job. Currently, the authors are not aware of any frac hit lawsuits that have resulted in any substantive law rulings.”).

323. Pierce, supra note 43, at 265.

324. See id. at 265 (proposing a reservoir community analysis for resolving the legal question). 
analysis leave room for consideration of any characteristics of the geologic reservoir. A court applying trespass would first determine whether the invasion was sufficiently physically intrusive to constitute a trespass. Unlike in most drainage-by-frac cases where fractures and proppants enter the plaintiff's property, the intruding agent in most frac hits cases is likely to be pressure. Courts following the dimensional test might not find this to be a physical intrusion, whereas courts that have adopted the reasoning of Martin $v$. Reynolds probably would. ${ }^{325}$ Trespass analysis may render opposite results in these two types of jurisdictions even where the underlying reservoir-use conflict is the same in both.

Even a modified trespass rule that privileges socially valuable physical intrusions may not render consistent outcomes, because frac hits cases involve two competing methods of exploiting the minerals in a reservoir - vertical and horizontal production - whose relative values will vary depending on reservoir characteristics and market conditions. This differs from the typical trespass-by-frac case, which presents a single method of mineral development set against the complaining owner's nonuse of the minerals. Consider Garza, where the societal value of fracking unconventional reservoirs justified infringement of the nonconsenting reservoir owners' property rights. In Garza the nonconsenting owners did not assert that their nonuse of the reservoir was better suited to developing the reservoir. In a typical frac-hit case, in contrast, both parties would be putting the reservoir to productive uses and would likely offer countervailing reasons their respective production techniques should prevail. Courts in these cases will be asked to evaluate the competing production techniques and the characteristics of the reservoir to determine the development scheme most likely to maximize efficient exploitation of the common reservoir.

Nuisance is the appropriate standard for making these kinds of evaluations. In considering the paradigm frac hits case a court applying utilitarian nuisance framework would start by determining the nature of the first-in-time vertical well operator's injury. The harm suffered by the vertical well operator from the horizontal well operator's frac job may be physical damage to the vertical well, diminished production from the vertical well, or having to completely shut in the vertical well. The harm in each case is interference with the vertical operator's ability to produce its portion of the common reservoir through its vertical well. This is a loss of the reservoir's use value to the operator. It does not matter whether the loss of use was caused by a physical intrusion, as by proppants, or merely by pressure changes from the horizontal frac job. 
The second step would be to determine whether the horizontal operator's frac job was justified despite the vertical operator's lost use value. An invasion is justified in nuisance doctrine when the utility of the conduct outweighs the gravity of the resulting harm. ${ }^{326}$ To determine whether the utility of the interfering conduct outweighs the gravity of the vertical operator's loss of reservoir use under this analysis, the court would consider the extent of the vertical operator's inability to produce the reservoir. A relatively minor decline in production would weigh in favor of finding the horizontal frac job to be reasonable. But a loss of all production from a well or the loss of all ability to produce the reservoir from a new well would weigh heavily in favor of compensating the vertical operator's loss.

Applying the Second Restatement, the court would further consider the parties' ability to avoid the harm. It would inquire about such facts as whether the horizontal operator could have designed its frac job differently without giving up efficiency, whether the vertical operator could have reinforced the casing of its vertical well by improving how it was cemented in the hole, and whether the vertical operator could have pooled its interest with the horizontal operator's before the horizontal well was drilled and completed. The court would also focus on the suitability of vertical and horizontal production techniques to the reservoir. If the reservoir is unconventional (like the Vicksburg T formation in Garza or the tight sand in Stone) horizontal drilling and massive frac operations would be necessary to produce the reservoir efficiently. If, on the other hand, the reservoir is conventional (e.g., a limestone formation) and production in the field is mature and mostly from vertical wells, the horizontal frac job would be out of place and less justifiable, especially if no horizontal wells have been drilled and proven economic in the field.

The court would also balance the public's interest in how the reservoir is managed by weighing the social utility of vertical and horizontal production. The public's interest is in the avoidance of waste of hydrocarbons, waste of reservoir pressure, and waste from drilling, equipping, and producing needless numbers of wells to produce the reservoir. ${ }^{327}$ The horizontal operator could justify its operations by showing that horizontal fracking is necessary to recover hydrocarbons from the reservoir that would otherwise be left behind by vertical production. The vertical operator could improve its case for compensation by showing that existing vertical production of the reservoir is sufficient

326. RESTATEMENT (SECOND) OF TORTS $§ 826$ (AM. LAW INST. 1969).

327. See Christiansen \& Pierce, supra note 5, at 11-12 (describing the public's interest in maximizing production and citing the Interstate Oil \& Gas Compact Commission's 2004 Model Oil $\&$ Gas Conservation Act). 
to maximize recovery of the hydrocarbons and thus that horizontal drilling and completions are needlessly expensive and wasteful.

If after evaluating these factors the court were to find that horizontal fracturing was justified, the vertical operator would have to suffer any lost production opportunity without compensation unless it could show that the loss is serious or severe. ${ }^{328}$ The vertical operator's loss may be serious or severe if, for instance, the horizontal completion would render impossible or noneconomic production of the reservoir from a vertical well anywhere on the vertical operator's lease. If the loss were shown to be serious, the vertical operator may be entitled to compensation, provided that the cost of compensation in this and similar cases would not render horizontal completions in the reservoir uneconomic. This may be a complex question, but it is necessary to avoid an outcome in which the most efficient means of production is barred as a practical matter even if it is otherwise permitted. ${ }^{329}$ If the harm were shown to be severe and such that the vertical operator should not have to suffer without compensation, the horizontal operator would be absolutely liable under the compensation principle. ${ }^{330}$

\section{F. Disputes Arising from CCS and Other Emerging Technologies}

There does not appear to be any reported case involving a subsurface invasion from CCS or other emerging techniques like ASR and CAES. ${ }^{331}$ As previously discussed, however, the potential for such disputes has helped stymie deployment of CCS technology. ${ }^{332}$ The prevailing understanding of subsurface property as possessory and subsurface encroachments as trespassory threatens to undermine this and other potentially beneficial technology in two broad ways. First, it would require a $\mathrm{CO}_{2}$ injector to obtain consent from the pore space owners of hundreds or thousands of square miles of property to avoid trespass liability from migrating $\mathrm{CO}_{2}{ }^{333}$ In this scenario the likelihood of holdouts, which could prevent the CCS project, is high. Second, the principle of absolute liability that flows from the possessory view would practically require a $\mathrm{CO}_{2}$ injector to insure against all damage caused by the injection. ${ }^{334}$ Because $\mathrm{CO}_{2}$ injection is likely to interfere with preexisting

328. As those terms are defined in the RESTATEMENT (SECOND) OF TORTS $\S \S 826 \& 829 \mathrm{~A}$, respectively.

329. RESTATEMENT (SECOND) OF TORTS $\S 826$ (b) (AM. LAW INST. 1969).

330. Id. § 829A.

331. For a description of ASR, CAES, and CCS technology, see supra Part I.B.

332. See supra section I.C.

333. See supra notes $47-50$ and accompanying text.

334. While the modern approach to subsurface trespass articulated by Professor Anderson may avoid the problem of obtaining unanimous consent, it nonetheless would impose absolute liability on 
commercial subsurface activities, ${ }^{335}$ the financial burden of compensating for resulting harm may well make CCS operations infeasible. The possessory view would similarly undermine any large-scale use of subsurface reservoir space for fluid storage, such as ASR or CAES.

The dual problems of aggregating consent and compensating resulting harm without undermining the economic feasibility of CCS would be more soluble if the legal system (and all the individual judges, scholars, and lawyers who comprise it) understood subsurface property as nonpossessory and invasions as nontrespassory. Under a nonpossessory view, aggregating the consent of all owners of potentially affected pore space would be unnecessary. A reservoir owner would not be entitled to exclude injected $\mathrm{CO}_{2}$ merely by virtue of owning an interest in the reservoir. Instead, an objecting owner could enjoin the injection operation only by showing actual damage to the owner's right of use and enjoyment and that the harm is not justified by injection's utility. ${ }^{336}$ The injector in such a case may avoid injunction by paying compensation for any harm suffered by the objecting owner and thus increasing the injection operation's utility. ${ }^{337}$ Nuisance doctrine thus replaces the need for consent with the option to pay reasonable compensation, thereby compelling the participation of holdout landowners.

Nuisance doctrine also furnishes a compensation scheme superior to strict liability. Whereas strict liability for damages resulting from publicly beneficial injection operations may render the operations economically infeasible, nuisance law contains provisions designed to avoid this result in all but the most extreme cases. Only when a landowner's ability to use her property is severely damaged and the damage is greater than the landowner "should have to bear without compensation" should a court applying nuisance law award compensation without considering the CCS operation's social value or viability. ${ }^{338}$

In cases not involving such severe harm, a landowner's right to full compensation for injury resulting from a socially beneficial CCS operation may be subordinated to the operator's right to continue the operation. Harm from CCS operations that is "serious" but not quite

the injector for actual damages from the injection. See Anderson, supra note 31, section III.B.1. Thus, even if modified under Professor Anderson's approach, the possessory view may impede deployment of socially valuable technologies.

335. See supra note 51 and accompanying text.

336. See Restatement (SECOND) OF TORTs $§ 826$ (Am. LAw. InST. 1969).

337. See id. cmt. e ("In a suit for damages, the legal utility of the activity may also be greatly reduced by the fact that the actor is operating the factory and producing the noise and smoke without compensating his neighbors for the harm done to them. The conduct for which the utility is being weighed includes both the general activity and what is done about its consequences.").

338. See id. § 829A; see also Lewin, supra note 111, at 231. 
"severe" would warrant compensation without regard to the operation's utility, but only if the financial burden of compensating this and similar losses would not cause the CCS operation to cease. ${ }^{339}$ In the absence of severe or serious harm an affected landowner would be entitled to damages only if, after considering evidence of the character of the locality, the character of the harm, and the social value of the parties' conflicting land uses, ${ }^{340}$ the court finds the gravity of the landowner's loss outweighs the utility of the CCS operation. ${ }^{341}$

Viewing subsurface property invasions as nuisances would mean resolving them under the same legal framework as nontrespassory invasions caused by above-ground waste storage activities. CCS projects would be treated much like landfills. When a landfill emits unreasonably foul smells into the surrounding neighborhood, for example, the law classifies harm done to neighbors' property a nuisance. The odor particles emanating from the landfill may diminish neighbors' ability to use or enjoy their property. It might prevent them from using the land in certain ways - perhaps operating a botanical garden - and reduce the value of their property for rent or sale. But the stench does not dispossess the neighbors of their property or of the airspace above it. When a neighbor sues the landfill to abate the odor or recover damages to compensate for lost use or enjoyment, the typical court balances the social value of the landfill against the gravity of harm from the externality. In so doing the court will attempt to efficiently coordinate the parties' competing uses of the semi-common airspace overlying their respective parcels of land.

\section{CONCLUSION}

If it walks like a nuisance and talks like a nuisance, it might be a nuisance. Courts de facto apply nuisance principles in subsurface interference cases because nuisance standards are designed to mediate competing uses of property to achieve maximally efficient results. In contrast, trespass seems inapplicable in situations involving unauthorized subsurface encroachments because they do not interfere with exclusivity and are not susceptible to a strict scheme of governance. Trespass is not

339. RESTATEMENT (SECOND) OF TORTS $§ 826($ b) (AM. LAW. INST. 1969); see also Lewin, supra note 111, at 231. The drafters of the Restatement explain that "[t]he extent of the burden of compensating may also affect the determination of what persons can recover. Thus in the case of a factory emitting smoke and odors, the granting of compensation for annoyance and inconvenience to all persons located in the general vicinity may create a burden so heavy as to make it not feasible to continue to operate the factory. Compensation may therefore be granted only to those in close vicinity to the plant whose annoyance is more severe, and not to those farther away whose annoyance is less." RESTATEMENT (SECOND) OF TORTS $\S 826 \mathrm{cmt}$. f.

340. Id. $\S 827$.

341. See id. $\S 826(a)$. 
the applicable tort regime to enforce incorporeal property interests, and thus contains standards inappropriate to that task.

Evidence that courts treat subsurface interferences as nontrespassory appears in the facts courts consider in determining liability. These typically include the social and economic value of the defendant's conduct, the commonness of the conduct in the area, and the severity of the harm suffered by the plaintiff. Where, as in most cases, the value of the defendant's activity is high, such as where it contributes to the prevention waste, and the plaintiff is unable to show actual damages other than the value of pore space invaded and occupied, courts tend to find no trespass. Yet these factors are not appropriate in determining injury to an owner's possession. They are appropriate, rather, in determining injury to the owner's reasonable use and enjoyment.

The true nature of the property interest at stake in subsurface interference cases is use and enjoyment. It is both logical and doctrinally appropriate to apply nuisance, because nuisance is the tort regime designed to remedy violations of the use right. Because trespass is the wrong standard for remedying infringement of the right to use property, applying trespass requires modifying the doctrine in meaningful ways. Nuisance principles were developed by courts to mediate conflicting uses of adjoining land and, consequently, provide better guidance for courts in resolving cases where subsurface activities collide. Nuisance also enables a more flexible tailoring of remedies where an unjustified interference is found.

Courts are already engaging in nuisance-like analyses; doing it expressly would aid the coherence of their decisions. Improving the coherence and predictability of courts' decision-making in these cases is not trivial. Development of commercial-scale CCS facilities, for example, requires the right to use hundreds or thousands of square miles of subsurface reservoir rights. The risk that offsetting subsurface owners may object to use of their pore space for $\mathrm{CO}_{2}$ storage has slowed, and currently threatens to paralyze, large-scale deployment of sequestration technology. The possibility that courts may apply a strict liability standard for any damages that may arise - whether or not such damage should be considered legal injury - may inhibit deployment of CCS and other useful subterranean technologies. 